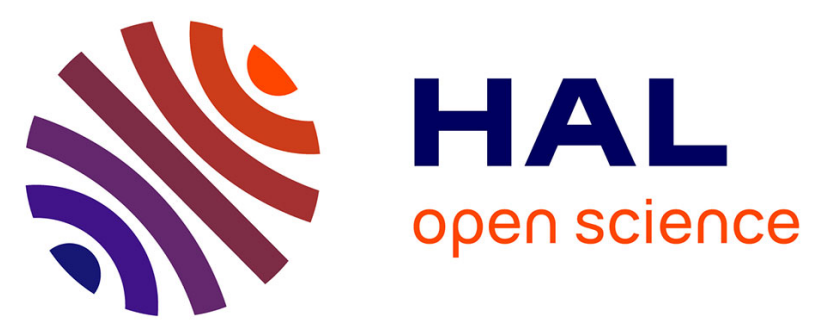

\title{
Degradation Mechanisms of Oxygen Evolution Reaction Electrocatalysts: A Combined Identical-Location Transmission Electron Microscopy and X-ray Photoelectron Spectroscopy Study
}

F. Claudel, Laetitia Dubau, G. Berthome, Lluís Solà-Hernández, Christian Beauger, L. Piccolo, Frédéric Maillard

\section{To cite this version:}

F. Claudel, Laetitia Dubau, G. Berthome, Lluís Solà-Hernández, Christian Beauger, et al.. Degradation Mechanisms of Oxygen Evolution Reaction Electrocatalysts: A Combined Identical-Location Transmission Electron Microscopy and X-ray Photoelectron Spectroscopy Study. ACS Catalysis, 2019, 9 (5), pp.4688-4698. 10.1021/acscatal.9b00280 . hal-02138787

\section{HAL Id: hal-02138787 https://hal.science/hal-02138787}

Submitted on 9 Nov 2020

HAL is a multi-disciplinary open access archive for the deposit and dissemination of scientific research documents, whether they are published or not. The documents may come from teaching and research institutions in France or abroad, or from public or private research centers.
L'archive ouverte pluridisciplinaire HAL, est destinée au dépôt et à la diffusion de documents scientifiques de niveau recherche, publiés ou non, émanant des établissements d'enseignement et de recherche français ou étrangers, des laboratoires publics ou privés. 


\section{Degradation Mechanisms of Oxygen Evolution Reaction Electrocatalysts: A Combined Identical- Location Transmission Electron Microscopy and X- Ray Photoelectron Spectroscopy Study}

Fabien Claudel, ,'+ Laetitia Dubau, ${ }^{\dagger}$ Grégory Berthomé, ${ }^{\ddagger}$ Lluis Sola-Hernandez,\$ Christian Beauger, $\$$ Laurent Piccolo," Frédéric Maillard",

† Univ. Grenoble Alpes, Univ. Savoie Mont Blanc, CNRS, Grenoble INP, LEPMI, 38000 Grenoble, France

‡ Univ. Grenoble Alpes, CNRS, Grenoble INP, SIMAP, 38000 Grenoble, France

$\S$ MINES ParisTech, PSL University, Centre procédés, énergies renouvelables et systèmes énergétiques (PERSEE), CS 10207 rue Claude Daunesse, F-06904 Sophia Antipolis Cedex, France 


\author{
"Univ Lyon, Université Claude Bernard - Lyon 1, CNRS, IRCELYON - UMR 5256, 2 Avenue
} Albert Einstein, F-69626 Villeurbanne CEDEX, France

\begin{abstract}
Determining the degradation mechanism of oxygen evolution reaction (OER) catalysts
\end{abstract} is fundamental to design improved polymer electrolyte membrane water electrolyser (PEMWE) devices but remains challenging under the demanding conditions of PEMWE anodes. To address this issue, we introduce a methodology combining identical-location transmission electron microscopy, X-ray photoelectron spectroscopy and electrochemical measurements, and apply it to iridium nanoparticles (NPs) covered by a thin oxide layer $\left(\mathrm{IO}_{\mathrm{x}}\right)$ in OER conditions. The results show that, whatever the initial OER activity of the $\mathrm{IrO}_{\mathrm{x}}$ nanocatalysts, it gradually declines and reaches similar values after 30,000 potential cycles between 1.20 and $1.60 \mathrm{~V}$ vs. RHE. This drop in OER activity was bridged to the progressive increase of the Ir oxidation state (fast change during electrochemical conditioning, milder changes during accelerated stress testing) along with increased 
concentration of hydroxyl groups and water molecules. In contrast, no change in the mean oxidation state, no change in the hydroxyl/water coverage and constant OER activity were noticed on the benchmark micrometre-sized $\mathrm{IrO}_{2}$ particles. Besides chemical changes, Ir dissolution/redeposition and $\mathrm{IrO}_{\mathrm{x}}$ nanoparticle migration/agglomeration/detachment were evidenced in OER conditions. By combining the information derived from identicallocation transmission electron microscopy (IL-TEM) images and X-ray photoelectron spectroscopy (XPS) measurements, we show that $\operatorname{Ir}(I I I)$ and $\operatorname{Ir}(\mathrm{V})$ are the best performing Ir valencies for the OER. These findings provide insights into the long-term OER activity of $\mathrm{IrO}_{\mathrm{x}}$ nanocatalysts, as well as practical guidelines for the development of more active and more stable PEMWE anodes.

KEYWORDS: Proton-exchange membrane water electrolysers; oxygen evolution reaction; iridium oxide; antimony-doped tin oxide; identical-location transmission electron microscopy. 


\section{INTRODUCTION}

During the $21^{\text {st }}$ Conference of the Parties held in Paris in 2015, 195 states have agreed

to limit global warming to an average of no more than $2{ }^{\circ} \mathrm{C}$ relative to pre-industrial level.

However, this ambitious objective will not be reached without integrating non-hydro renewables in the energy mix $^{1}$. Additionally, the intermittency of alternative energies calls for a joint development of energy storage systems such as water electrolyzers ${ }^{2-3}$. Of the three main water electrolysis technologies (alkaline, proton exchange membrane (PEM) and solid oxide), PEM water electrolysers (PEMWEs) feature several advantages: they are compact, withstand dynamic operating conditions, and can operate under pressure and at high current densities. However, the massive production of PEMWEs requires (i) enhancing the rate of the oxygen evolution reaction (OER), (ii) improving the durability of the anodic catalytic material, and (iii) decreasing the cost of the catalytic layers e.g. by reducing the noble metal content. 
Experimental work performed more than 40 years ago has established that ruthenium oxide $\left(\mathrm{RuO}_{2}\right)$ is the most efficient catalyst towards the OER in alkaline media but this oxide is unstable in acidic media ${ }^{4-9}$. Iridium oxide $\left(\mathrm{IrO}_{2}\right)$ is also highly active for the OER, chemically stable, a good electronic conductor but suffers of its high cost and scarcity especially when used in the form of micrometer-sized particles as it is in state-of-the-art PEMWE anodes ${ }^{5-8,}$ 10-16. Solutions to diminish the iridium (Ir) content have been intensively investigated, for example partial substitution of Ir by a transition metal11-12, 1722 and/or decrease of the size of the Ir crystallites to the nanometer scale ${ }^{23-24}$. However, the very oxidizing environment of PEMWE anodes (electrochemical potential $E>2.0 \mathrm{~V}$ $v s$. the reversible hydrogen electrode - RHE, presence of oxygen, highly acidic environment) renders classical high surface area carbon supports unstable ${ }^{25}$ and requires the development of alternatives such as metal oxides ${ }^{26-29}$. In addition, it is wellestablished that the chemical nature and the crystallographic structure of the $\operatorname{IrO}_{x}$ are keys to high and sustainable OER activity; in particular thermal oxides are known to be less active but more stable than electrochemically formed oxides ${ }^{30-35}$. However, because the energy of the metal-oxygen bonds is stronger than that of the oxygen-oxygen bonds, ${ }^{6}$ 
metal-oxygen bonds are permanently formed and broken in OER conditions. Thus, the chemical composition and the intrinsic activity of OER catalysts continuously change in PEMWE anode operating conditions more specifically at the nanometre-scale ${ }^{33,36-37}$.

Surprisingly, despite its great fundamental and technological interest, the fate of supported-IrO $\mathrm{x}_{\mathrm{x}}$ nanocatalysts in OER conditions has never been studied hitherto. To adresss this issue, we introduce for the first time a methodology combining identicallocation transmission electron microscopy (IL-TEM), X-ray photoelectron spectroscopy (XPS) and electrochemical measurements, and apply it to iridium nanoparticles (NPs) covered by a thin oxide layer.

RESULTS AND DISCUSSION

Initial Morphology, Structure and Chemical Composition of Antimony-doped Tin Oxidesupported and Carbon-supported $\mathrm{IrO}_{\mathrm{x}}$ Nanoparticles 
Figure 1a-h shows TEM images $\mathrm{IrO}_{\mathrm{x}} \mathrm{NPs}$ supported on Vulcan $\mathrm{XC}-72\left(\mathrm{IrO}_{\mathrm{x}} / \mathrm{C}\right)$ or on antimony-doped tin oxide aerogel $\left(\mathrm{IrO}_{x} / \mathrm{ATO}\right)$ synthesized in house using the same colloidal solution, and two commercial catalysts: metallic Ir NPs supported on Vulcan XC72 (Ir/C comm.) and $\mathrm{IrO}_{2}$ powder $\left(\mathrm{IrO}_{2}\right.$ comm.). In the $\mathrm{IrO}_{x} / \mathrm{C}$ catalyst, the metal NPs feature an average diameter of $1.9 \pm 0.5 \mathrm{~nm}$ and are homogeneously distributed onto the carbon support. The $\mathrm{IrO}_{\mathrm{x}} / \mathrm{ATO} \mathrm{NPs}$ exhibit similar size $(2.0 \pm 0.5 \mathrm{~nm})$ but are more agglomerated when supported on ATO. Similar observations were made by Cognard et al. ${ }^{38}$ on $\mathrm{Pt} / \mathrm{C}$ and Pt/ATO nanocatalysts, and the differences of agglomeration were ascribed to different specific surface areas of the supports. Finally, a mix of large aggregates and small NPs co-exist in the commercial $\mathrm{Ir} / \mathrm{C}$ and $\mathrm{IrO}_{2}$ catalysts, thus explaining why the crystallite size of Ir/C exceeds the nanoparticle size.

The X-ray diffraction patterns (Figure $1 \mathbf{i}, \mathbf{j}$ ) indicate that $\mathrm{Ir} / \mathrm{C}$ comm. is essentially metallic, and that small amorphous or poorly crystallize) $\mathrm{IrO}_{2}$ nanocrystallites and large metallic Ir crystallites co-exist in the $\mathrm{IrO}_{2}$ comm. sample. The presence of broad diffraction peaks for $\mathrm{IrO}_{x} / \mathrm{C}$ and $\mathrm{IrO}_{x} / \mathrm{ATO}$ suggests small and/or amorphous NPs in these samples. 
No reflection typical of tetragonal $\mathrm{IrO}_{2}$ (PDF card $\mathrm{n}^{\circ}$ 04-009-8479) was detected in the assynthesized and benchmark materials.
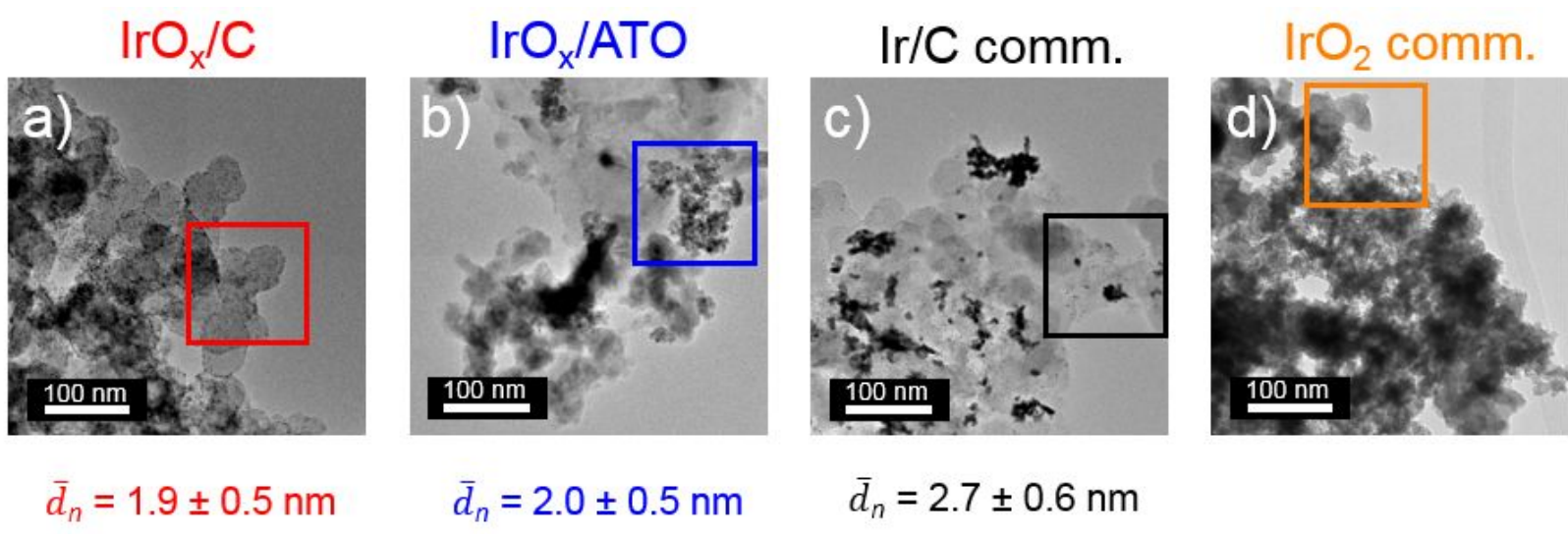

$$
\bar{d}_{n}=2.7 \pm 0.6 \mathrm{~nm}
$$
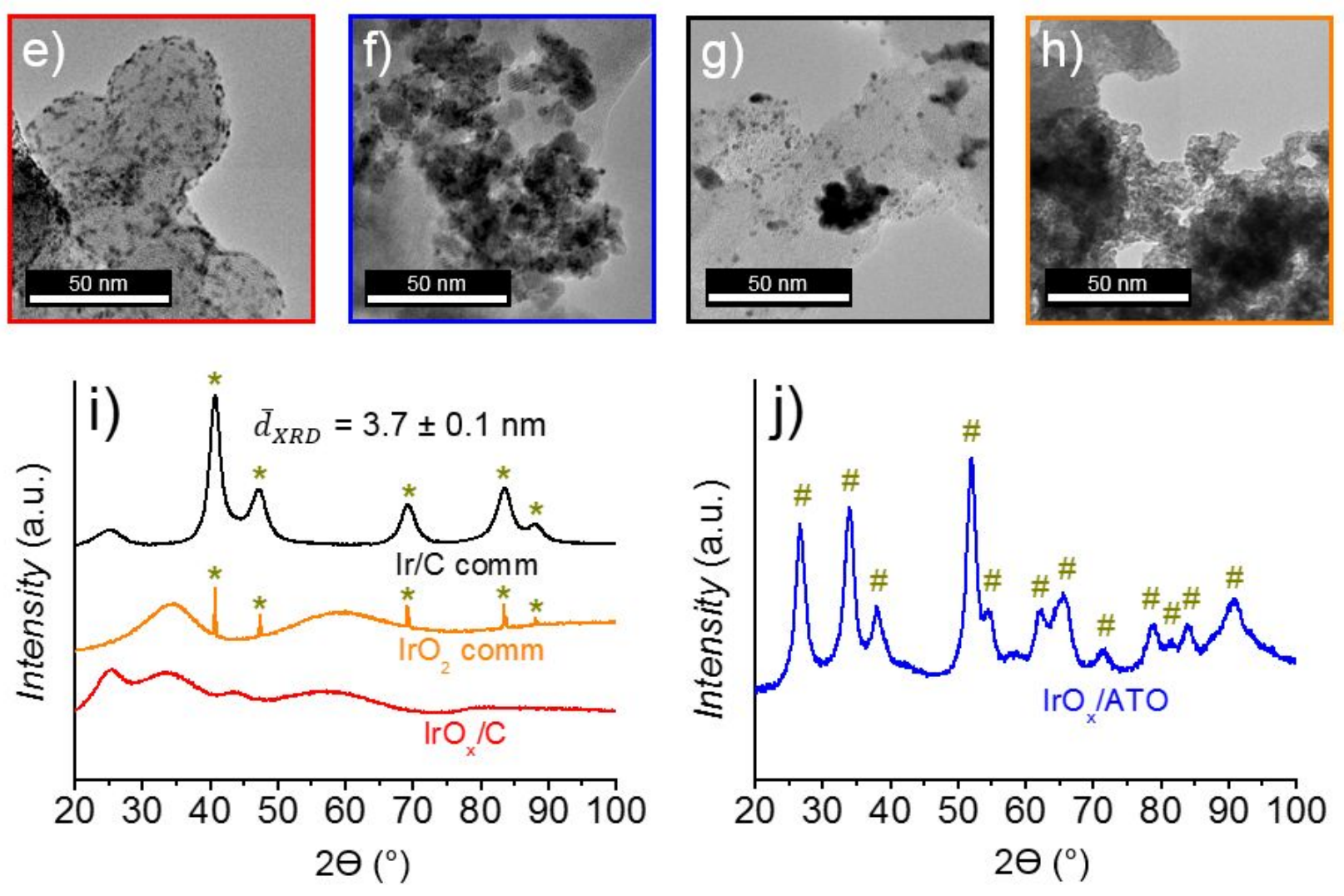
Figure 1. TEM images of $\mathrm{IrO}_{x} / \mathrm{C}(\mathrm{a}, \mathrm{e}), \mathrm{IrO}_{x} / \mathrm{ATO}(\mathrm{b}, \mathrm{f}), \mathrm{Ir} / \mathrm{C}$ comm. (c, g) and $\mathrm{IrO}_{2}$ comm. (d, h). X-ray diffractograms of $\mathrm{Ir} / \mathrm{C}$ comm., $\mathrm{IrO}_{2}$ comm. and $\mathrm{IrO}_{\mathbf{x}} / \mathrm{C}(\mathrm{i})$, and $\mathrm{IrO}_{\mathbf{x}} / \mathrm{ATO}(\mathrm{j})$. The star and the hash symbols correspond to cubic Ir (PDF card $n^{\circ} 00-006-0598$ ) and tetragonal $\mathrm{SnO}_{2}$ (PDF card $\mathrm{n}^{\circ}$ 00-041-1445), respectively. No reflection typical of tetragonal $\mathrm{IrO}_{2}$ (PDF card $\mathrm{n}^{\circ}$ 04-009-8479) was detected in the as-synthesized and benchmark materials.

Insights into the chemical nature of the $\mathrm{IrO}_{\mathrm{x}}$ surface atoms were obtained by XPS measurements. The Ir $4 \mathrm{f}$ spectra displayed in Figure 2 were fitted using the parameters and the line shapes recently provided by Freakley et al. ${ }^{39}$ (see Table S1 and Materials and Methods for more details). Four contributions were considered: metallic $\operatorname{Ir}$, $\operatorname{Ir}(\mathrm{III}), \operatorname{Ir}(\mathrm{IV})$ and $\operatorname{Ir}(\mathrm{V})$ species. Figure 2 and Table $\mathrm{S} 2$ indicate that: (i) $\mathrm{Ir} / \mathrm{C}$ comm. is essentially metallic (Figure 2c), (ii) $\operatorname{Ir}(\mathrm{IV})$ species predominate in the $\mathrm{IrO}_{x} / \mathrm{C}$ (Figure 2a) and $\mathrm{IrO}_{2}$ comm. (Figure 2d) catalysts and that (iii) despite the same colloidal solution was used for the 
synthesis of $\mathrm{IrO}_{x} / \mathrm{C}$ and $\operatorname{IrO} \mathrm{X}_{x} /$ ATO catalysts, metallic $\operatorname{Ir}, \operatorname{Ir}(\mathrm{III}), \operatorname{Ir}(\mathrm{IV})$, and $\operatorname{Ir}(\mathrm{V})$ species coexist in the fresh $\mathrm{IrO}_{x} /$ ATO (Figure $2 \mathrm{~b}$ ).
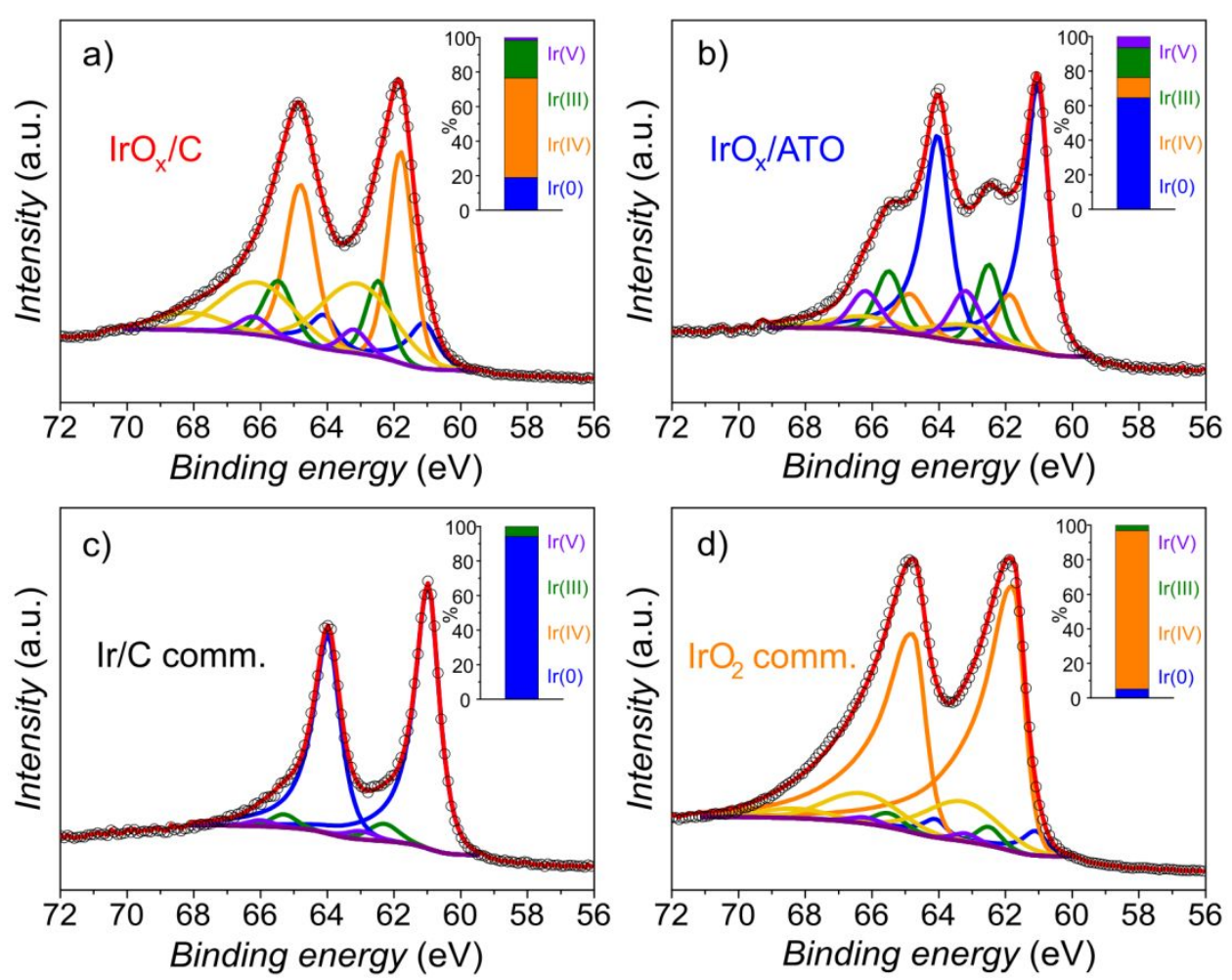
the theoretical contribution of $\operatorname{Ir}(\mathrm{III})$ satellites and $\operatorname{Ir} 5 \mathrm{p}_{1 / 2}$, respectively) to the areas of the peaks located at 63.1 and $66.1 \mathrm{eV}$.

\section{Electrocatalytic Activity for the Oxygen Evolution Reaction in Acidic Electrolyte}

Changes of the cyclic voltammograms (CVs) during 'electrochemical conditioning' (100 potential cycles between 0.05 and $1.40 \mathrm{~V} v s$. RHE at $500 \mathrm{mV} \mathrm{s}^{-1}$ ) confirmed the XPS results. Indeed, the electrical charge associated with the adsorption/desorption of underpotentially-deposited hydrogen $\left(\mathrm{H}_{\text {upd }}\right)$ gradually decreased during the conditioning cycles on Ir/C comm. (Figure 3a). In contrast, the CVs stabilized after ca. 25 potential cycles for the $\mathrm{IrO}_{x} / \mathrm{C}$ catalyst (Figure $3 b$ ), thus confirming that the $\mathrm{IrO}_{x} / C$ NPs were partly oxidized in the fresh state. An intermediate behaviour was observed for the $\mathrm{IrO}_{x} / \mathrm{ATO}$ catalyst (Figure 3c): $\mathrm{H}_{\text {upd }}$ features were observed during the first conditioning cycles but rapidly disappeared highlighting that the NPs were in average more metallic in $\mathrm{IrO}_{x} /$ ATO than in $\mathrm{IrO}_{x} / \mathrm{C}$. Last, the $\mathrm{CVs}$ measured on $\mathrm{IrO}_{2}$ comm. featured no change (Figure 3d), in agreement with the predominance of $\operatorname{Ir}(\mathrm{IV})$ species in this catalyst. 
Ohmic-drop corrected polarization curves in $0.05 \mathrm{M} \mathrm{H}_{2} \mathrm{SO}_{4}$ (Figure 4a-c) were used to determine the OER activities of the different nanocatalysts. We are aware that a fraction of the measured current arises from the electrochemical dissolution of the $\mathrm{IrO}_{x} \mathrm{NPs}$. However, based on dissolution rates of 10 and $0.1 \mathrm{ng} \mathrm{cm}^{-2}$ established for metallic Ir and $\mathrm{IrO}_{2}$ electrodes, respectively ${ }^{40}$ we estimated that the Ir dissolution current contributed to less than $0.05 \%$ to the total electrical charge of the OER polarization curve.
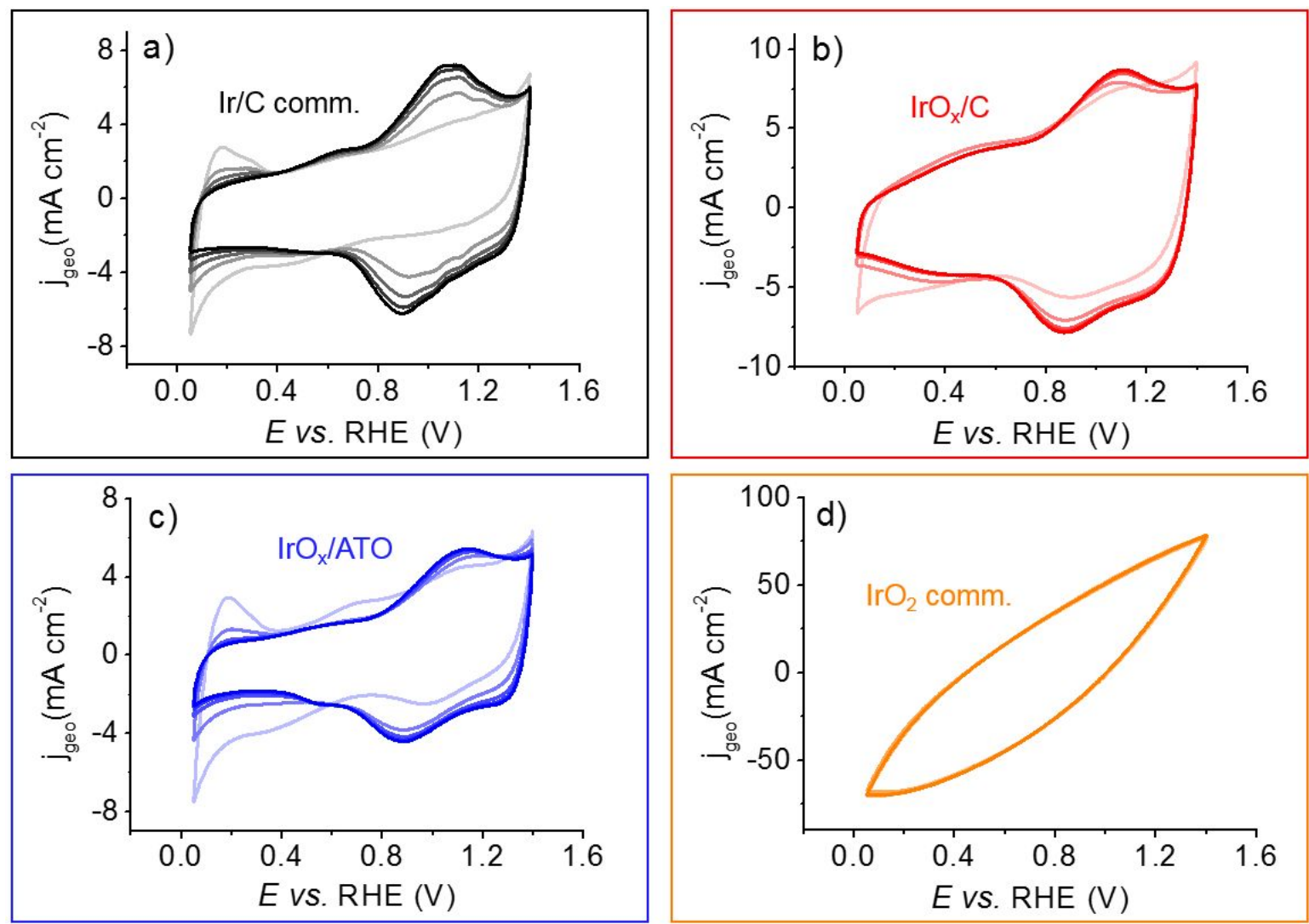
Figure 3. Conditioning cycles between 0.05 and $1.40 \mathrm{~V}$ vs. RHE in Ar-saturated $0.05 \mathrm{M}$ $\mathrm{H}_{2} \mathrm{SO}_{4}$ electrolyte on (a) Ir/C comm., (b) $\mathrm{IrO}_{x} / \mathrm{C}$, (c) $\mathrm{IrO}_{x} / \mathrm{ATO}$ and (d) $\mathrm{IrO}_{2}$ comm. The potential sweep rate was $500 \mathrm{mV} \mathrm{s}^{-1}$. The shades of colours (lightest to darkest) represent the $2^{\text {nd }}, 25^{\text {th }}, 50^{\text {th }}, 75^{\text {th }}$ and $100^{\text {th }}$ potential cycles.

The Ohmic-drop corrected OER current measured at $1.51 \mathrm{~V} v s$. RHE $(\eta=280 \mathrm{mV})$ normalized by the initial mass of Ir on the electrode $\left(j_{\text {mass }}\right)$ or by the anodic charge obtained after integration of the current between 0.40 and $1.40 \mathrm{~V} v s$. RHE $\left(j_{\text {spec }}\right)$ and the background corrected OER specific activities using $\mathrm{IrO}_{\mathrm{x}} \mathrm{NPs}$-free supports ( $\dot{\mathrm{spec}}_{\text {support }}$ ) is displayed in Figure 4d, Figure $4 \mathrm{e}$ and Figure $4 \mathrm{f}$, respectively. The mass activity towards the OER of all catalysts approached the recent record value of $100 \mathrm{~A} \mathrm{glr}^{-1}$ reported in Ref. ${ }^{41}$ and reached an optimal value for $\mathrm{IrO}_{x} / \mathrm{C}\left(221 \pm 14 \mathrm{~A} \mathrm{~g}_{\mathrm{Ir}}{ }^{-1}\right)$. Using the conclusions derived from XPS spectra (Table S2), we can thus confidently confirm that amorphous nanometer-sized Ir oxides containing a mixture of $\operatorname{Ir}(0), \operatorname{Ir}(\mathrm{III})$ and $\operatorname{Ir}(\mathrm{IV})$ species better 
perform than crystalline nanometer-sized Ir oxides containing predominantly $\operatorname{Ir}(\mathrm{IV})$ species ${ }^{36}$.
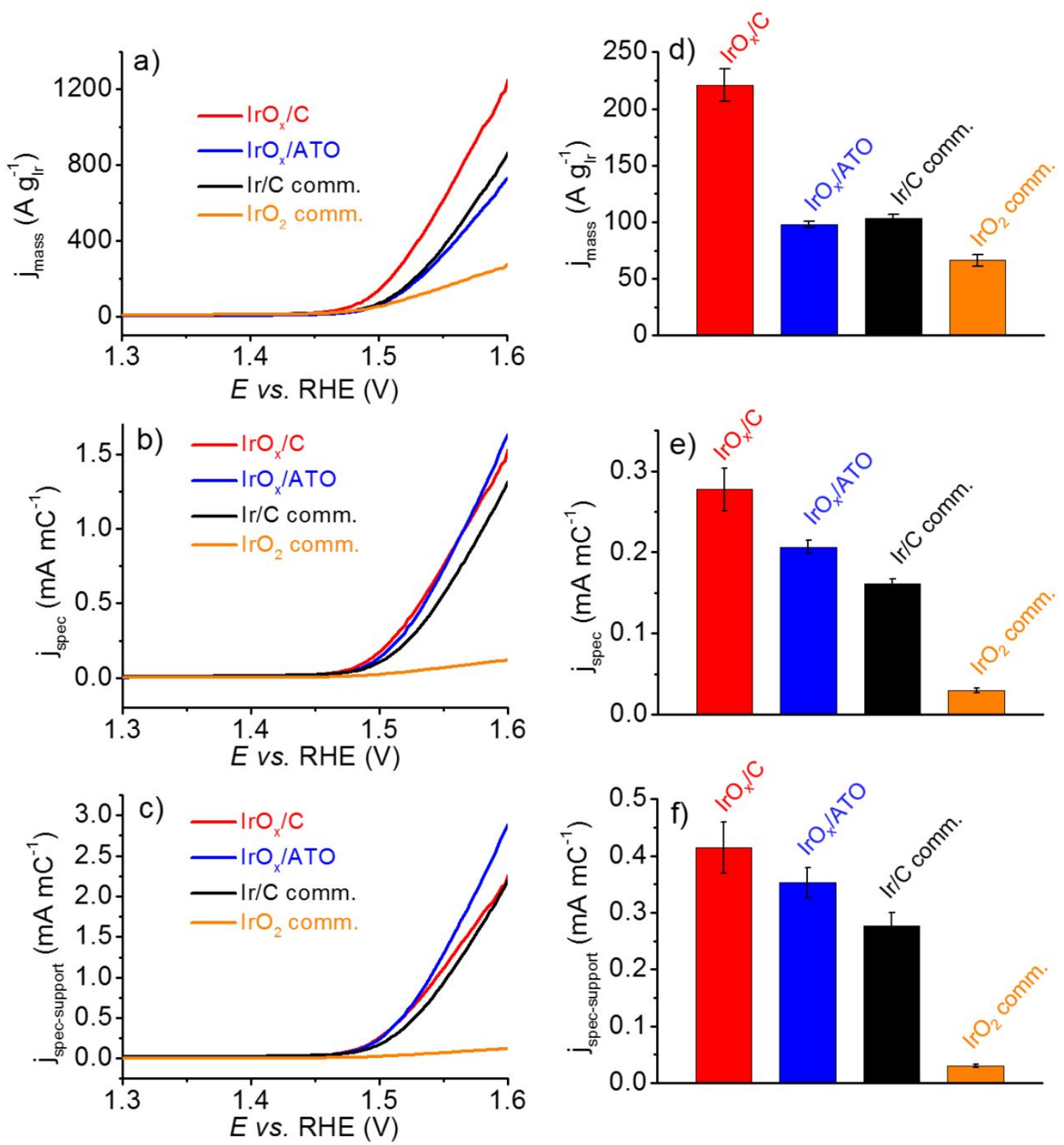

Figure 4. Ohmic-drop corrected polarization curves measured between 1.20 and $1.60 \mathrm{~V}$ vs. RHE at $5 \mathrm{mV} \mathrm{s}^{-1}$ and $293 \mathrm{~K}$ in Ar-saturated $0.05 \mathrm{M} \mathrm{H}_{2} \mathrm{SO}_{4}$. The OER current was 
determined at $E=1.51 \mathrm{~V}$ vs. RHE, and normalized by (a) the mass of Ir initially loaded

onto the electrode $\left(j_{\text {mass }}\right)$, (b) the anodic charge obtained by integrating the current between 0.40 and $1.40 \mathrm{~V} v s . \mathrm{RHE}\left(j_{\text {spec }}\right)$, and $(\mathrm{c})$ the anodic charge obtained by integrating the current between 0.40 and $1.40 \mathrm{~V} v s$. RHE after background subtraction ( $\left.j_{\text {spec-support }}\right)$. The experiments were repeated three times and the error bars correspond to the standard deviation of the measurements.

\section{Changes of the Oxygen Evolution Reaction Activity in OER Conditions}

The catalytic powders were then electrochemically aged using an accelerated stress test (AST) comprising 30,000 potential steps between 1.20 and $1.60 \mathrm{~V} v s$. RHE with square-wave potential ramp ( $3 \mathrm{~s}$ at each potential). Figure $5 \mathrm{a}-\mathrm{d}$ show the $\mathrm{CV}$ s measured on the fresh and aged $\mathrm{Ir} / \mathrm{C}$ comm., $\mathrm{IrO}_{x} / \mathrm{C}, \mathrm{IrO}_{x} / \mathrm{ATO}$ and $\mathrm{IrO}_{2}$ comm. catalysts. For all materials, except $\mathrm{IrO}_{2}$ comm., the anodic charge between 0.40 and $1.40 \mathrm{~V}$ vs. RHE increased during the first $1,000(1 \mathrm{k})$ potential cycles, more remarkably on $\mathrm{rO}_{x} / \mathrm{C}$, suggesting continuous growth of an electrochemical oxide layer ${ }^{17}, 42$. Also, a peak 
commonly associated to the $\operatorname{Ir}(\mathrm{III}) / \mathrm{Ir}(\mathrm{IV})$ transition ${ }^{33,43-44}$ was noticed at $c a .0 .97 / 0.93 \mathrm{~V}$ vs. RHE (positive-and negative-going potential sweep, respectively) on the three supported catalysts. This peak was broad for the fresh $\mid \mathrm{rO}_{x} / \mathrm{C}$ and $\mid \mathrm{IO}_{x} / \mathrm{ATO}$ but it sharpened and shifted towards negative potentials during the first AST cycles, thus suggesting a change in the nature of the surface species (Figure $5 \mathrm{~b}$ and Figure $5 \mathrm{c}$ ). It was already sharp and negatively shifted for the fresh Ir/C comm. catalyst (Figure 5a). Remarkably, another redox peak emerged at $1.20 \mathrm{~V} v s$. RHE (positive-going potential sweep) after $10,000(10 \mathrm{k})$ potential cycles on $\mathrm{IrO}_{x} / \mathrm{C}$ or after $4,000(4 \mathrm{k})$ potential cycles on $\mathrm{IrO}_{\mathrm{x}} / \mathrm{ATO}$ and $\mathrm{Ir} / \mathrm{C}$ comm. It was formerly documented by Saveleva et al. ${ }^{36}$ and by Oh et al..$^{24}$ for Ir@IrO ${ }_{x}$ catalysts and Ir nanodendrites, respectively. Oh et al. ${ }^{24}$ ascribed this peak to the transition of $\operatorname{Ir}(\mathrm{IV})$ to $\operatorname{Ir}(\mathrm{V})$ although this change in $\operatorname{Ir}$ oxidation state may occur at ca. $1.40-1.45 \mathrm{~V} v s$. RHE, as suggested by the redox peaks observed on the CVs in

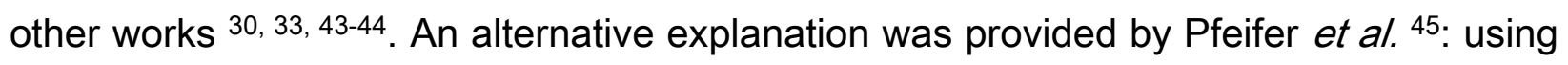
density functional theory, these authors proposed that this peak should be rather ascribed to the oxidation of $\mathrm{O}(-\mathrm{II})$ in $\mathrm{O}(-\mathrm{I})$. They predicted a standard potential approaching 1.20 $1.30 \mathrm{~V} v s$. RHE for this reaction, in excellent agreement with our results. 


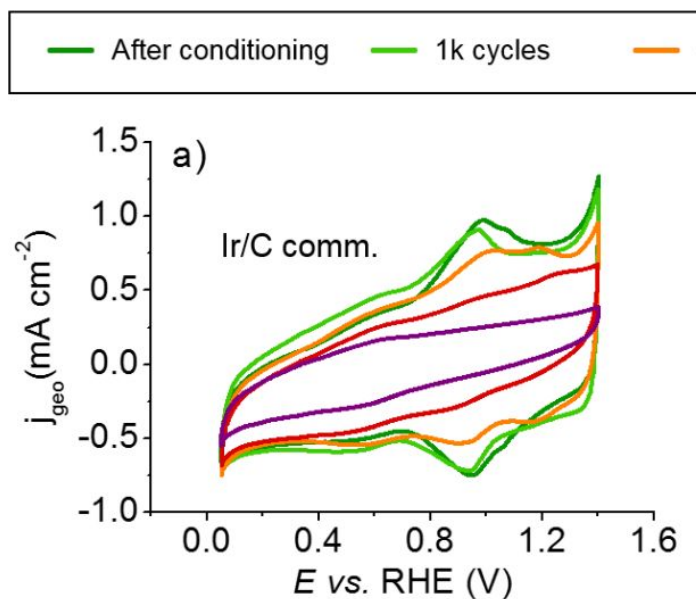

$$
4 \mathrm{k} \text { cycles } \quad-10 \mathrm{k} \text { cycles } \quad-30 \mathrm{k} \text { cycles }
$$
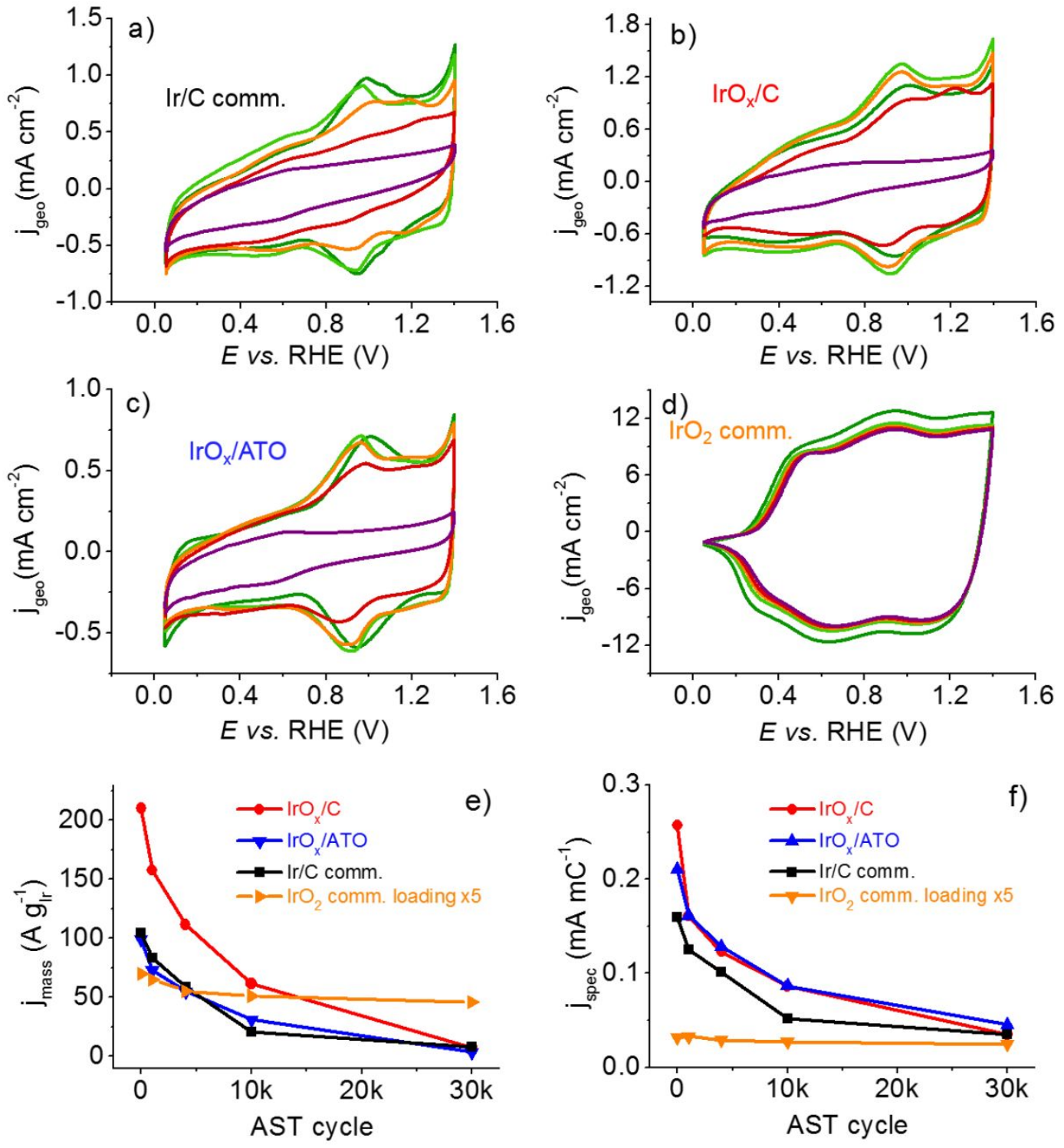

Figure 5. Cyclic voltammograms recorded in Ar-saturated $0.05 \mathrm{M} \mathrm{H}_{2} \mathrm{SO}_{4}$ at $50 \mathrm{mV} \mathrm{s}^{-1}$ at $293 \mathrm{~K}$ after the conditioning step (100 cycles between 0.05 and $1.40 \mathrm{~V} v$ s. RHE) and after $1,000,4,000,10,000$ and 30,000 potential cycles between 1.20 and $1.60 \mathrm{~V}$ vs. RHE 
for a) Ir/C comm., b) $\mathrm{IrO}_{x} / \mathrm{C}$, c) $\mathrm{IrO}_{x} /$ ATO and d) $\mathrm{IrO}_{2}$ comm. Changes of the OER catalytic activity measured at $1.51 \mathrm{~V} v s$. RHE as a function of the number of cycles for the four catalysts investigated in this study. The OER activity was normalized by e) the mass of Ir initially loaded onto the electrode ( $j_{\text {mass }}$ ) and f) the anodic charge obtained by integrating the current between 0.40 and $1.40 \mathrm{~V} v s$. RHE (jpec $)$.

As shown by Figure $5 e$ and Figure $5 f$, the OER performance dropped for all supported catalysts during the AST. $\mathrm{IrO}_{x} / \mathrm{C}$ remained the most active electrocatalyst both from mass and specific activity perspectives during the first $10 \mathrm{k}$ potential cycles but $\mathrm{IrO}_{2} \mathrm{comm}$. revealed the most robust catalyst in terms of mass activity towards the OER (Figure 5e), the most important metrics in terms of PEMWE device. Fitting the Tafel plots in the linear region of the $\eta=f\left(\log \left(j_{\text {mass }}\right)\right)$ plots (Figure S2) confirmed the drop in performance during the AST. In the fresh state, Tafel slopes of 52 and $50 \mathrm{mV} \mathrm{dec}^{-1}$ were obtained for $1 \mathrm{rO} \mathrm{X}_{\mathrm{x}} / \mathrm{C}$ and $\mathrm{IrO}_{\mathrm{x}} / \mathrm{ATO}$, respectively and higher values were obtained for $\mathrm{Ir} / \mathrm{C}$ comm. and $\mathrm{IrO}_{2}$ comm. (58 and $78 \mathrm{mV} \mathrm{dec}{ }^{-1}$, respectively). These values increased on all supportedelectrocatalysts after $10 \mathrm{k}$ potential cycles. 


\section{Morphological Evolution of the Nanocatalysts during AST Monitored by IL-TEM}

To disclose chemical composition-morphology-OER activity relationships, the morphological changes occurring on $\mathrm{IrO}_{x} / \mathrm{C}$, $\mathrm{IrO}_{x} / \mathrm{ATO}$ and $\mathrm{Ir} / \mathrm{C}$ comm. during the AST were assessed using IL-TEM. The IL-TEM images were recorded in the fresh state (assynthesized), after conditioning, and after $1 \mathrm{k}, 4 \mathrm{k}, 10 \mathrm{k}$ and $50 \mathrm{k}$ potential cycles. Key to these measurements was to use a TEM grid made of titanium (indeed, gold TEM grids dissolve at potential $\left.>1.40 \mathrm{~V} v s . \mathrm{RHE}^{46}\right)$. To the best of our knowledge, this is the first time that IL-TEM measurements are performed in OER conditions.

The changes in morphology for the three supported nanocatalysts are displayed in Figure 6. Quantitative information was derived from the IL-TEM images: the average Feret diameter was measured for the exact same NPs in the fresh state, and after conditioning, $1 \mathrm{k}, 4 \mathrm{k}, 10 \mathrm{k}$ and $50 \mathrm{k}$ potential cycles. The NP size distributions of the fresh and aged $\mathrm{IrO}_{\mathrm{x}} / \mathrm{C}, \mathrm{IrO} \mathrm{X}_{\times} / \mathrm{ATO}$ and $\mathrm{Ir} / \mathrm{C}$ comm. catalysts determined by eye-counting using the ImageJ software (automated determination revealed less precise, see Figure S5) are 
displayed in Figure 7, Figure S3 and Figure S4, respectively. They show that the smallest

$\mathrm{IrO}_{x} / \mathrm{C}$ and $\mathrm{IrO}_{x} /$ ATO NPs preferentially disappeared during the conditioning step along with a small increase in NP size, thus suggesting that Ostwald ripening occurred during this stage. In contrast, during the AST, crystallite migration/agglomeration/coalescence and detachment of the largest $\mathrm{IrO}_{\mathrm{x}} \mathrm{NPs}$ were the predominant degradation mechanisms. These results are in excellent agreement with the inductively-coupled plasma mass spectrometry results of Cherevko et al.43-44, $47-48$ pointing towards dissolution of bulk Ir surfaces in similar potential conditions. They also agree with thermodynamics, ${ }^{49}$ as $\operatorname{~Ir~}^{3+}$ ions produced by dissolution can redeposit in the metallic form only onto for potentials below ca. $1.16 \mathrm{~V} v s$. RHE that is during the conditioning step. 


\section{Support}

Crystallite migration corrosion/displacement Ir dissolution/redeposition $\square$ s

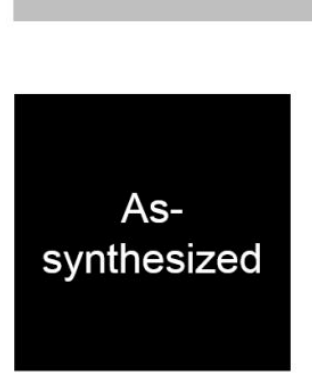

$$
\mathrm{IrO}_{\mathrm{x}} / \mathrm{C} \quad \mathrm{IrO} / \mathrm{ATO} \quad \mathrm{Ir} / \mathrm{C} \text { comm. }
$$
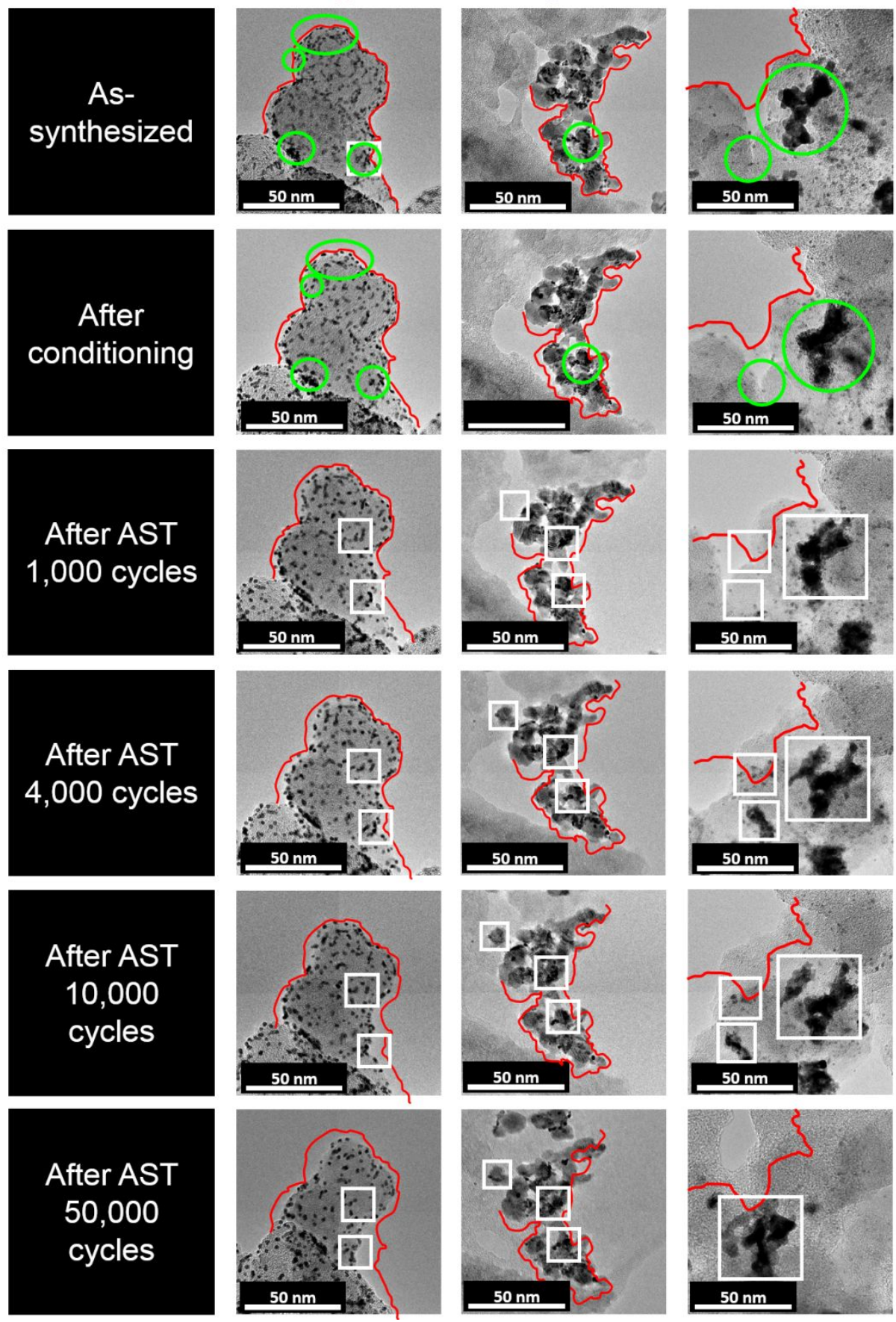

ACS Paragon Plus Environment 
Figure 6. IL-TEM images of $\mathrm{IrO}_{x} / \mathrm{C}, \mathrm{IrO}_{x} / \mathrm{ATO}$ and $\mathrm{Ir} / \mathrm{C}$ comm. as-synthesized, after the conditioning step $(0.05<E<1.60 \mathrm{~V} v s . \mathrm{RHE})$ and after different stages of potential cycling between $1.20<E<1.60 \mathrm{~V} v s$. RHE, highlighting major degradation mechanisms occurring during OER.

Along with Ir dissolution, a strong corrosion of Vulcan XC72 was noticed, in line with thermodynamics ${ }^{49}$ and with former results showing massive carbon corrosion at potentials above $1.50 \mathrm{~V} v s$. RHE ${ }^{50-51}$. It is noteworthy that the ATO support was also corroded in OER conditions, indicating mild or no positive metal/metal-oxide support interaction effect. This statement was supported by X-EDS measurements showing a gradual loss of $\mathrm{Sb}$ atoms from the conditioning stage leading. After $50 \mathrm{k}$ potential cycles, there was no $\mathrm{Sb}$ remaining in the ATO aerogel thus attenuating the ability of the $\operatorname{IrO}_{x} \mathrm{NPs}$ to exchange electrons. These results are in line with former report by Cognard et al. ${ }^{52}$ showing dissolution and concomitant restructuration of ATO in PEMFC cathode operating conditions. By combining rotating disk and rotating ring disk electrode, X-ray energy dispersive X-ray spectroscopy and inductively-coupled plasma mass spectrometry, the 
authors showed that both $\mathrm{Sb}$ and $\mathrm{Sn}$ atoms are dissolved from ATO. The concomitant restructuration of the ATO support was accelerated during potential excursions at low electrode potential, e.g. during electrochemical characterizations or kinetic measurements. 


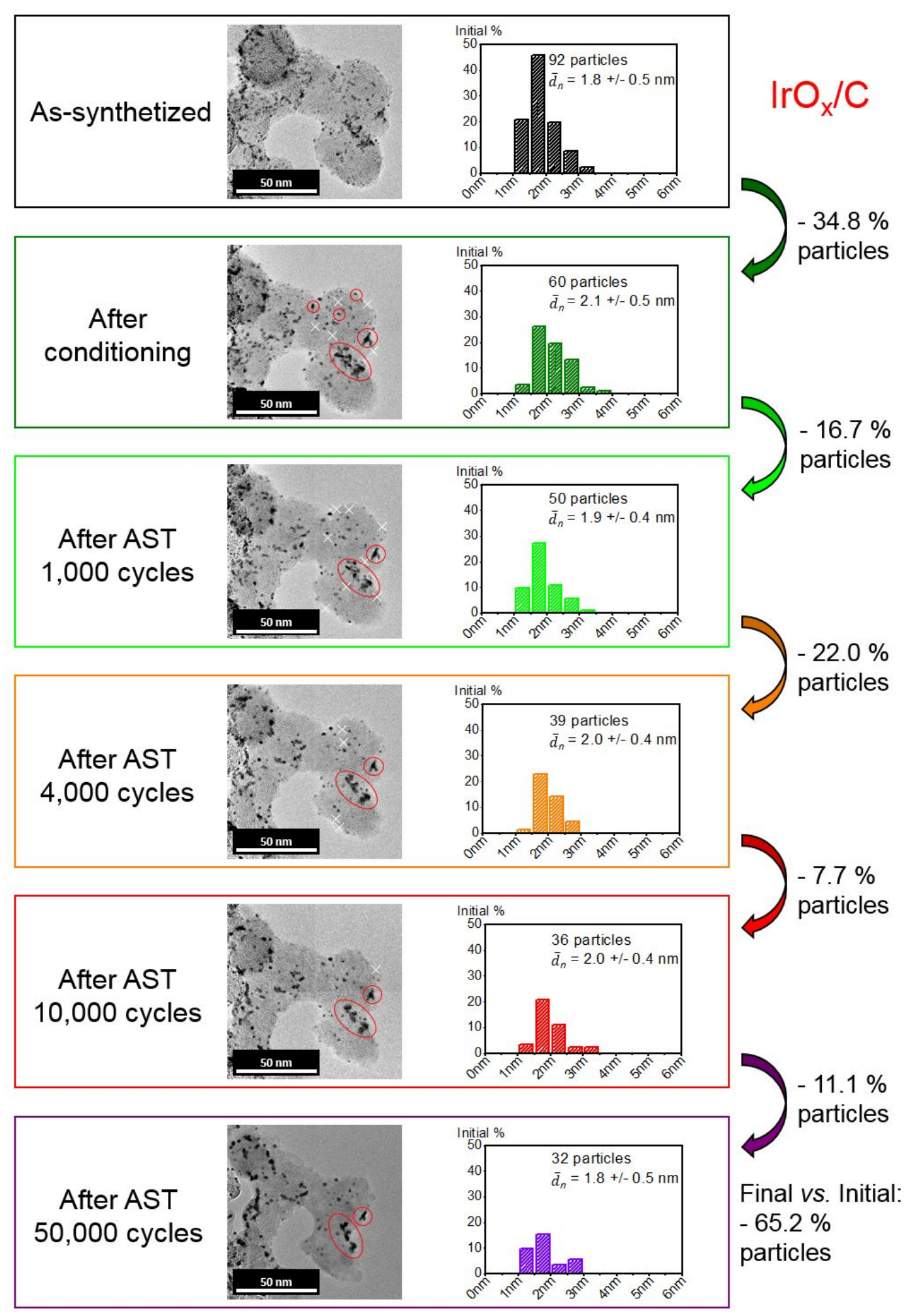


Figure 7. IL-TEM images and associated changes of the particle size distribution for $\mathrm{IrO}_{\mathrm{x}} / \mathrm{C}$ during potential cycling between $1.20<E<1.60 \mathrm{~V}$ vs. RHE at $T=298 \mathrm{~K}$. Only isolated particles were considered to build the histograms. Red ellipses were used to highlight migration/agglomeration/coalescence of $\mathrm{IrO}_{\mathrm{x}} \mathrm{NPs}$ and white crosses highlight their detachment. The number-averaged average Feret diameter $\left(\bar{d}_{n}\right)$ is plotted in the histograms.

\section{Compositional Evolution of the Nanocatalysts During AST Monitored by XPS}

Changes in the chemical composition of $\mathrm{IrO}_{x} / \mathrm{C}, \mathrm{IrO}_{x} / \mathrm{ATO}, \mathrm{Ir} / \mathrm{C}$ comm. and $\mathrm{IrO}_{2}$ comm. during the AST were also monitored. As indicated by Figure 8 , the $\operatorname{Ir} 4 \mathrm{f}_{7 / 2}$ band typically shifted to higher binding energy for all supported catalysts indicating an increase in the oxidation state. This result agrees with the early findings of Kötz et al. ${ }^{33}$ on anodic Ir oxide films. Similarly, Li et al. ${ }^{53}$ polarized a 100 nm-thick Ir film at $1 \mathrm{~mA} \mathrm{~cm}{ }^{-2}$ for 4,69 or 120 hours. Based on XPS measurements, the authors claimed that metastable Ir-O species first form and then transform into $\mathrm{IrO}_{2}$ in OER conditions. The results displayed in Figure 
8 confirm these findings but they also indicate that $\operatorname{Ir}(\mathrm{III}), \operatorname{Ir}(\mathrm{IV})$ and $\operatorname{Ir}(\mathrm{V})$ species co-exist in the aged nanocatalysts, in agreement with the operando XPS results of SanchezCasalongue ${ }^{37}$ and the $\mathrm{X}$-ray absorption near-edge spectroscopy (XANES) measurements of Minguzzi et al. ${ }^{54-55}$. Therefore, the mixture of Ir valencies observed after the AST can be rationalized by considering an Ir cation red-ox mechanism, such as that recently proposed by Cherevko et al.44:

$$
\begin{aligned}
& \operatorname{IrO}(\mathrm{OH}) \rightarrow \mathrm{IrO}_{2}+\mathrm{H}^{+}+\mathrm{e}^{-} \\
& \mathrm{IrO}_{2}+\mathrm{H}_{2} \mathrm{O} \rightarrow \operatorname{IrO}_{2}(\mathrm{OH})+\mathrm{H}^{+}+\mathrm{e}^{-}
\end{aligned}
$$

In which $\mathrm{IrO}_{2}(\mathrm{OH})$ species eventually chemically decompose into $\mathrm{IrO}(\mathrm{OH})$ and $\mathrm{O}_{2}{ }^{44}$ :

$$
2 \mathrm{IrO}_{2}(\mathrm{OH}) \rightarrow 2 \mathrm{IrO}(\mathrm{OH})+\mathrm{O}_{2}
$$




\begin{abstract}
Alternatively, based on operando near-ambient pressure X-ray photoelectron and absorption spectroscopy results, Pfeifer et al. ${ }^{45,56-57}$ and Saveleva et al. ${ }^{36}$ proposed that the oxygen $(\mathrm{O})$ anions rather than the Ir cations play a key role in the OER mechanism ( $\mathrm{O}$ anion red-ox mechanism). These authors argue that $\mathrm{O}(-\mathrm{I})$ anions are formed via an electrochemical step. However, because of their electron-deficient nature, $\mathrm{O}(-\mathrm{I})$ anions are prone to nucleophilic attack by water molecules hence favouring the $\mathrm{O}-\mathrm{O}$ bond formation through a chemical step ${ }^{58-59}$. Finally, other mechanisms consider both the electronic transitions of $\mathrm{O}$ and Ir atoms and assume that lattice $\mathrm{O}$ atoms participate in the OER mechanism, leading to the formation of oxygen vacancies and dissolution of Ir atoms 60-63.
\end{abstract}

In the light of our results, we assigned Reaction (1) to the $\operatorname{Ir}(\mathrm{III}) / \operatorname{Ir}(\mathrm{IV})$ redox couple observed at ca. $0.95 \mathrm{~V}$ vs. RHE, and Reaction (2) to the $\operatorname{Ir}(\mathrm{IV}) / \operatorname{Ir}(\mathrm{V})$ redox peak emerging

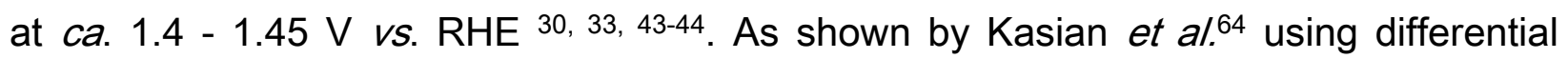
electrochemical mass spectrometry, the fate of $\operatorname{Ir}(\mathrm{III})$ species depends on the value of the electrochemical potential: at low electrochemical potential ( $E<1.6 \mathrm{~V} v s$. $\mathrm{RHE}), \operatorname{Ir}(\mathrm{III})$ 
species are oxidized to $\operatorname{Ir}(\mathrm{V})$ whereas at high electrochemical potential, $\operatorname{Ir}(\mathrm{V})$ species are further oxidized leading ultimately to formation of gaseous $\mathrm{IO}_{3}$.

Besides the increase of the mean oxidation state of Ir, the O1s XPS spectra (Figure S6) and the $\mathrm{O} 1 \mathrm{~s} / \mathrm{Ir} 4 \mathrm{f}$ integrated intensities ratios (Table S3) evidence that the fraction of $\mathrm{OH}$ species and water molecules adsorbed on $\mathrm{IrO}_{\mathrm{x}} / \mathrm{C}$ and $\mathrm{Ir} / \mathrm{C}$ comm. increased during the AST. In contrast, no change in the hydroxyl/water coverage was noticed on the benchmark micrometre-sized $\mathrm{IrO}_{2}$ particles. Our findings are in line with the experimental observations of Abbott et al. ${ }^{65}$ after an AST composed of 250 potential steps between 1.00 and $1.60 \mathrm{~V}$ vs. RHE. Combining the XPS results in the O1s region with the changes observed in the CVs during the AST (Figure 5), we thus assign the peak emerging at ca. $1.20 \mathrm{~V}$ vs. RHE during the AST to the oxidation of $\mathrm{O}(-\mathrm{II})$ in $\mathrm{O}(-\mathrm{I})$ (reaction (4) proposed by Pfeifer et $\left.a l^{45}\right)$ :

$\mathrm{IrO}_{\mathrm{x}} \mathrm{O}(-\mathrm{II}) \mathrm{H} \rightarrow \mathrm{IrO}_{\mathrm{x}} \mathrm{O}(-\mathrm{I})+\mathrm{H}^{+}+\mathrm{e}^{-}$ 
As-synthesized
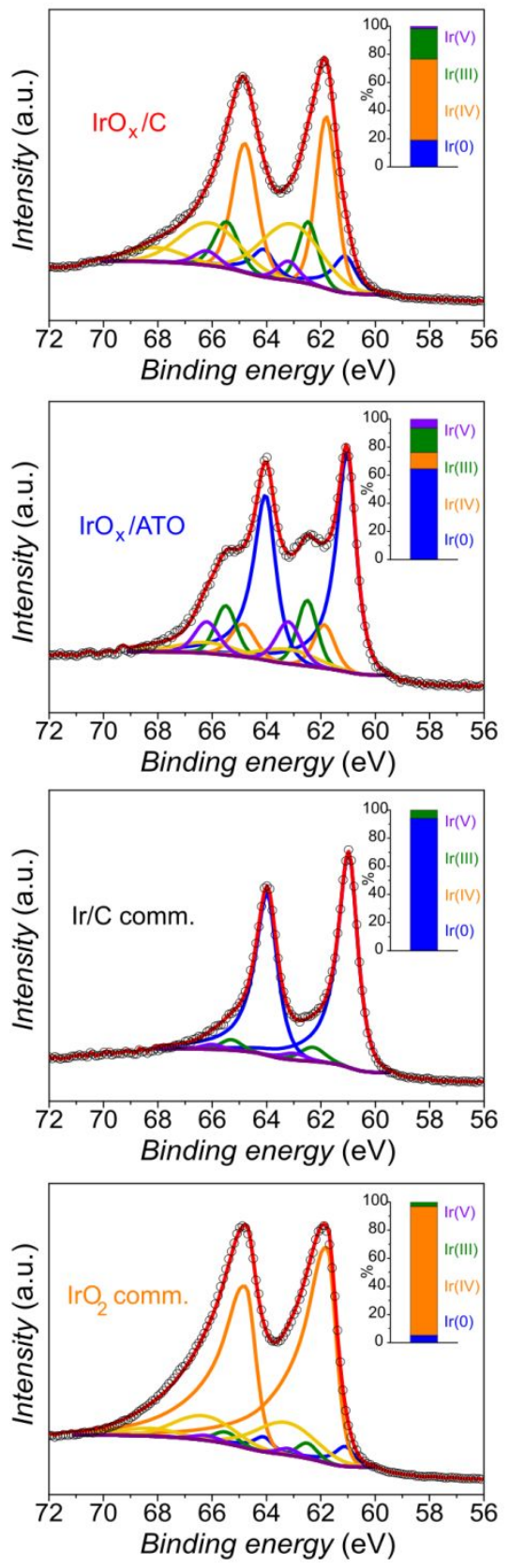

AST 10,000 cycles
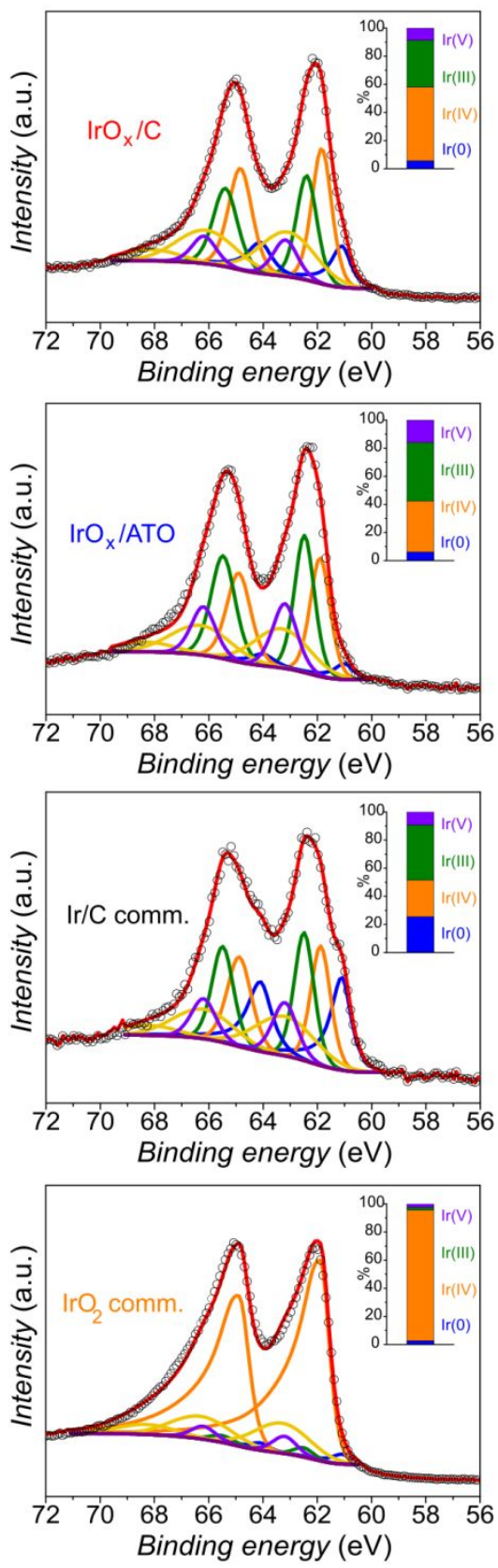

AST 30,000 cycles
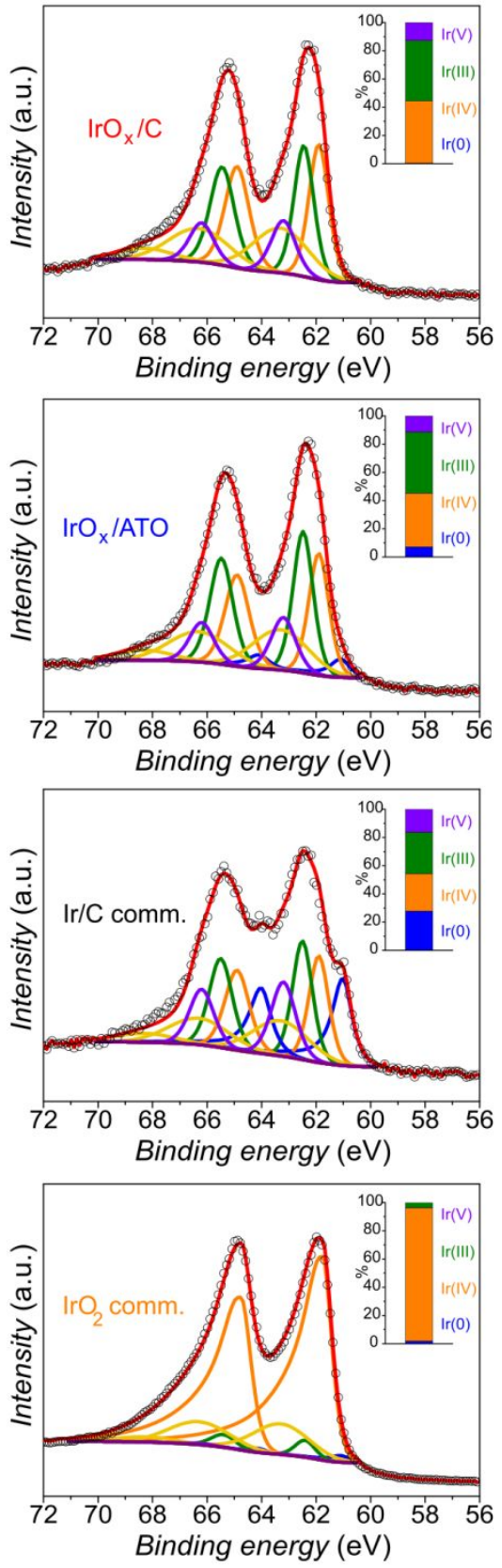

O Measured —Fit enveloppe $-\operatorname{Ir}(0)-\operatorname{Ir}(\mathrm{IV})-\operatorname{Ir}(\mathrm{III})-\operatorname{Ir}(\mathrm{IV})_{\text {sat }}-\operatorname{Ir}(\mathrm{V})+\operatorname{Ir}(\mathrm{III})_{\text {sat }}+\operatorname{Ir} 5 \mathrm{p}^{1 / 2} \quad$ - Background 
Figure 8. X-ray photoelectron spectra of the Ir4f level on $\mathrm{IrO}_{x} / \mathrm{C}, \mathrm{IrO} / \mathrm{ATO}, \mathrm{Ir} / \mathrm{C}$ comm. and $\mathrm{IrO}_{2}$ comm. before and after 10,000 and 30,000 potential cycles. Insets show the percentage of $\operatorname{Ir}(0), \operatorname{Ir}(\mathrm{IV}), \operatorname{Ir}(\mathrm{III})$ and $\operatorname{Ir}(\mathrm{V})$. To estimate the intensity of the peak ascribed to the $\operatorname{Ir}(\mathrm{V})$ component, we subtracted $15 \%$ of the area of the peak attributed to $\operatorname{Ir}(\mathrm{III})$ and $2.67 \%$ of the total area of the Ir4f band (to account for the theoretical contribution of $\operatorname{Ir}(\mathrm{III})$ satellites and $\operatorname{Ir} 5 \mathrm{p}_{1 / 2}$, respectively) to the areas of the peaks located at 63.1 and $66.1 \mathrm{eV}$.

\section{Disclosing Chemical Composition - OER Activity - Stability Relationships}

To disclose chemical composition - OER activity- stability relationships, the information obtained from IL-TEM and XPS were combined. We assumed that the OER activity of the $\mathrm{IrO}_{\mathrm{x}} \mathrm{NPs}$ after $10 \mathrm{k}$ potential cycles can be expressed as:

$$
\frac{100 \times j_{\text {meas }}}{(1-\% \text { lost })}=j(\operatorname{Ir}(0)) \times \%(\operatorname{Ir}(0))+j(\operatorname{Ir}(I V)) \times \%(\operatorname{Ir}(I V))+j(\operatorname{Ir}(I I I / V)) \times \%(\operatorname{Ir}(I I I)+\operatorname{Ir}(V))
$$


Where $j_{\text {meas }}$ is the background and Ohmic-drop corrected OER specific activity after $10 \mathrm{k}$ potential cycles extracted from Figure S7, \% lost is the percentage of lost electrochemically active surface area between the conditioning step and the $10 \mathrm{k}$ potential cycled sample estimated using IL-TEM images, $j(\operatorname{Ir}(A))$ is the intrinsic OER specific activity of Ir in the oxidation state $+\mathrm{A}$, and $\%(\operatorname{Ir}(A))$ is the fraction of oxide in the oxidation state $+\mathrm{A}$ estimated from XPS spectra fits. Since the $+\mathrm{III}$ and $+\mathrm{V}$ oxidation states of Ir are related by Equation (3), their intrinsic contributions to the intrinsic OER activity were considered interdependent.

\footnotetext{
Applying Equation (5) to $\mathrm{IrO}_{x} / \mathrm{C}, \mathrm{IrO}_{x} / \mathrm{ATO}, \mathrm{Ir} / \mathrm{C}$ comm. (due to the micrometre-size of the particles, IL-TEM measurements could not be performed on the $\mathrm{IrO}_{2}$ comm. catalyst) led to a system of three equations and three unknowns, which was solved, and the calculated intrinsic OER specific activity values of $\operatorname{Ir}(0), \operatorname{Ir}(I I / \mathrm{V})$ and $\operatorname{Ir}(\mathrm{IV})$ are presented in Table 1. Verification of the results was achieved by comparing the measured $(j$ meas $)$ and calculated values $\left(j_{c a l c}\right)$ of the OER specific activity after the conditioning step (Table 2)
} 
and the values used for the calculation and for the verification are given in Table $\$ 4$ and

\section{Table S5.}

Table 1. Calculated intrinsic OER specific activity values of $\operatorname{Ir}(0), \operatorname{Ir}(\mathrm{III} / \mathrm{V})$ and $\operatorname{Ir}(\mathrm{IV})$.

\begin{tabular}{ccc}
\hline & $j\left(\mathrm{~mA} \mathrm{mC}^{-1}\right)$ & OER activity contribution (\%) \\
\hline$j_{\text {calc }}(\operatorname{Ir}(0))$ & 0.0539 & 16.3 \\
$j_{\text {calc }}(\operatorname{Ir}(\mathrm{III} / \mathrm{V}))$ & 0.2373 & 71.5 \\
$j_{\text {calc }}(\operatorname{Ir}(\mathrm{IV}))$ & 0.0406 & 12.2 \\
\end{tabular}

Table 2. Verification of the model using the measured $\left(i_{\text {meas }}\right)$ and calculated $\left(j_{\text {calc }}\right)$ OER activities after the conditioning step.
$\mathrm{IrO}_{\mathrm{x}} / \mathrm{C}$
$\mathrm{IrO}_{\mathrm{x}} / \mathrm{ATO}$
Ir/C comm.
$\mathrm{IrO}_{2}$ comm. 


\begin{tabular}{ccccc}
\hline$j_{\text {meas }}\left(\mathrm{mA} \mathrm{mC}^{-1}\right)$ & 0.3793 & 0.3726 & 0.2660 & 0.03152 \\
$j_{\text {calc }}\left(\mathrm{mA} \mathrm{mC}^{-1}\right)$ & 0.1118 & 0.1700 & 0.1563 & 0.0491 \\
& & & & \\
Error (\%) & 70.5 & 54.4 & 41.2 & 35.8 \\
\hline
\end{tabular}

In view of the assumptions (areas analysed in IL-TEM and XPS representative of the sample) and the uncertainties (size and shape of nanoparticles, chemical composition) associated with the different physico-chemical measurements, we first stress that the values of OER activities calculated from Equation (5) must be regarded as semiquantitative. Despite this, some interesting findings emerge from Table 1. First, the results indicate that the combined Ir (III) and $\operatorname{Ir}(\mathrm{V})$ valencies are far more active for OER than $\operatorname{Ir}(0)$ and $\operatorname{Ir}(\mathrm{IV})$, thus confirming the better OER activity of Ir oxyhydroxides reported in the literature $30-31,33$. This trend is independent on the OER mechanism since $\operatorname{the} \operatorname{Ir}(\mathrm{III})$ valency plays a key role both in the $\operatorname{Ir}$ cation red - ox mechanism $(\operatorname{Ir}(\mathrm{III})-\operatorname{Ir}(\mathrm{IV})-\operatorname{Ir}(\mathrm{V})$ transitions $\left.{ }^{33,} 37,54-55,64\right)$ and in the $\mathrm{O}$ anion red-ox mechanism (the $\operatorname{Ir}(\mathrm{III})$ valency is the most likely to accommodate electrophilic $O(-I)$ species $\left.{ }^{45}\right)$. Second, the results of the 
combined IL-TEM - XPS - electrocatalytic measurements indicate that the progressive increase of the $\operatorname{Ir}(\mathrm{IV})$ fraction associated with the decrease in the number of isolated nanoparticles (due to Ir dissolution and migration/agglomeration/coalescence/detachment of the $\mathrm{IrO}_{\mathrm{x}}$ nanoparticles) concomitantly contribute to the drop of the OER mass activity in the long-term.

\section{CONCLUSION}

In conclusion, by combining accelerated stress tests, IL-TEM and XPS measurements, we rationalized OER activity losses in simulated PEMWE anode operating conditions. ILTEM images showed that $\mathrm{IrO}_{\mathrm{x}}$ NPs are prone to dissolve during the conditioning stage and migrate/agglomerate/coalesce/detach in OER conditions, independently on the type of support (Vulcan XC72 and ATO). XPS analyses revealed that these morphological changes are accompanied by gradual oxidation of $\operatorname{Ir}(0)$ and $\operatorname{Ir}(\mathrm{III})$ into $\operatorname{Ir}(\mathrm{IV})$ and $\operatorname{Ir}(\mathrm{V})$ species along with increased concentration of hydroxyl groups and water molecules on $\mathrm{IrO}_{\mathrm{x}}$ nanocatalysts. In contrast, no change in the mean oxidation state, no change in the 
hydroxyl/water coverage and constant OER activity were noticed on the benchmark micrometre-sized $\mathrm{IrO}_{2}$ particles. Our results thus indicate that the progressive increase of the Ir fraction with +IV valency associated with the decrease in the number of isolated nanoparticles concomitantly contribute to the drop of the specific activity towards the OER in practical PEMWE anode operating conditions.

\section{ASSOCIATED CONTENT}

\section{Supporting Information.}

The Supporting Information is available free of charge via the Internet at http://pubs.acs.org. It comprises:

- Materials and Methods

- XPS spectra (Ir4f bands) of Ir/C comm. after $10 \mathrm{k}$ potential cycles.

- Changes of the Tafel slopes for all catalysts during the $10 \mathrm{k}$ potential cycling protocol. 
- Identical-location transmission electron microscopy of $\mathrm{IrO}_{\mathrm{x}} / \mathrm{ATO}$ and $\mathrm{Ir} / \mathrm{C}$ comm. during the $50 \mathrm{k}$ potential cycling protocol.

- Comparison of $\mathrm{IrO}_{x} \mathrm{NP}$ size distribution achieved by automated determination or by eyecounting.

- XPS spectra (O1s band) of $\mathrm{IrO}_{x} / \mathrm{C}$, Ir/C comm. and $\mathrm{IrO}_{2}$ comm., before and after $10 \mathrm{k}$ and $30 \mathrm{k}$ potential cycles.

- Changes of the OER catalytic activity as a function of the number of AST cycles for all catalysts.

- Parameters used to fit the XPS spectra (Ir4f and O1s band).

- Atomic percentages of the different Ir valencies for the as-synthesized catalysts.

- $01 \mathrm{~s} / \mathrm{lr} 4 \mathrm{f}$ integrated intensities ratios for the as-synthesized and aged (10 k or $30 \mathrm{k}$ potential cycles) $\mathrm{IrO}_{x} / \mathrm{C}, \mathrm{Ir} / \mathrm{C}$ comm. and $\mathrm{IrO}_{2}$ comm. catalysts. 
- Values used for the calculation of the intrinsic OER activities of the different Ir valencies obtained after $10 \mathrm{k}$ potential cycles and values used to check this calculation obtained after the conditioning step.

\author{
AUTHOR INFORMATION \\ Corresponding Authors \\ *E-mail address for F.C: fabien.claudel@grenoble-inp.org \\ *E-mail address for F.M: frederic.maillard@lepmi.grenoble-inp.fr
}

\title{
Author Contributions
}

\begin{abstract}
All authors analysed, discussed the results, drew conclusions and approved the final version of this manuscript.
\end{abstract}

CONFLICT OF INTEREST

The authors declare no competing financial interest. 


\section{ACKNOWLEDGEMENTS}

This work was performed within the framework of the Centre of Excellence of Multifunctional Architectured Materials "CEMAM" $\mathrm{n}$ •ANR-10-LABX-44-01. The French National Research Agency (MOISE project, grant number ANR-17-CE05-0033) financially supported this research. F.C. acknowledges the Region Auvergne RhônesAlpes for funding his Ph.D. thesis in the frame of the ARC Energies program (ARC 2016 $\mathrm{n}^{\circ} 04$ ADR). Luis Cardenas (IRCELYON) is acknowledged for complementary XPS measurements.

\section{REFERENCES}

1. Lund, H., Renewable Energy Strategies for Sustainable Development. Energy. $2007,32,912-919$.

2. Millet, P.; Mbemba, N.; Grigoriev, S. A.; Fateev, V. N.; Aukauloo, A.; Etiévant, C., Electrochemical Performances of PEM Water Electrolysis Cells and Perspectives. Int. J. Hydrogen Energy. 2011, 36, 4134-4142. 
3. Carmo, M.; Fritz, D. L.; Mergel, J.; Stolten, D., A Comprehensive Review on PEM

Water Electrolysis. Int. J. Hydrogen Energy. 2013, 38, 4901-4934.

4. Miles, M. H.; Thomason, M. A., Periodic Variations of Overvoltages for Water Electrolysis in Acid Solutions from Cyclic Voltammetric Studies. J. Electrochem. Soc. $1976,123,1459-1461$.

5. Miles, M. H.; Klaus, E. A.; Gunn, B. P.; Locker, J. R.; Serafin, W. E.; Srinivasan, S., The Oxygen Evolution Reaction on Platinum, Iridium, Ruthenium and Their Alloys at $80^{\circ} \mathrm{C}$ in Acid Solutions. Electrochim. Acta. 1978, 23, 521-526.

6. Trasatti, S., Electrocatalysis in the Anodic Evolution of Oxygen and Chlorine. Electrochim. Acta. 1984, 29, 1503-1512.

7. Kötz, R.; Stucki, S., Stabilization of $\mathrm{RuO}_{2}$ by $\mathrm{IrO}_{2}$ for Anodic Oxygen Evolution in Acid Media. Electrochim. Acta. 1986, 31, 1311-1316.

8. Matsumoto, Y.; Sato, E., Electrocatalytic Properties of Transition Metal Oxides for Oxygen Evolution Reaction. Mater. Chem. Phys. 1986, 14, 397-426. 
9. Cheng, J. B.; Zhang, H. M.; Chen, G. B.; Zhang, Y. N., Study of $\operatorname{Ir}_{x} \mathrm{Ru}_{1-x} \mathrm{O}_{2}$ Oxides as Anodic Electrocatalysts for Solid Polymer Electrolyte Water Electrolysis. Electrochim. Acta. 2009, 54, 6250-6256.

10. Andolfatto, F.; Durand, R.; Michas, A.; Millet, P.; Stevens, P., Solid Polymer Electrolyte Water Electrolysis: Electrocatalysis and Long-Term Stability. Int. J. Hydrogen Energy. 1994, 19, 421-427.

11. Da Silva, L. A.; Alves, V. A.; Da Silva, M. A. P.; Trasatti, S.; Boodts, J. F. C., Oxygen Evolution in Acid Solution on $\mathrm{IrO}_{2}+\mathrm{TiO}_{2}$ Ceramic Films. A Study by Impedance, Voltammetry and SEM. Electrochim. Acta. 1997, 42, 271-281.

12. Chen, G.; Chen, X.; Yue, P. L., Electrochemical Behavior of Novel Ti//rO $\mathrm{I}_{x}-\mathrm{Sb}_{2} \mathrm{O}_{5^{-}}$ $\mathrm{SnO}_{2}$ Anodes. J. Phys. Chem. B. 2002, 106, 4364-4369.

13. Rasten, E.; Hagen, G.; Tunold, R., Electrocatalysis in Water Electrolysis with Solid Polymer Electrolyte. Electrochim. Acta. 2003, 48, 3945-3952. 
14. Hu, J. M.; Zhang, J. Q.; Cao, C. N., Oxygen Evolution Reaction on $\operatorname{IrO}_{2}$-Based DSA $^{\circledR}$ Type Electrodes: Kinetics Analysis of Tafel Lines and EIS. Int. J. Hydrogen Energy. 2004, 29, 791-797.

15. Song, S.; Zhang, H.; Ma, X.; Shao, Z.; Baker, R. T.; Yi, B., Electrochemical Investigation of Electrocatalysts for the Oxygen Evolution Reaction in PEM Water Electrolyzers. Int. J. Hydrogen Energy. 2008, 33, 4955-4961.

16. Mayousse, E.; Maillard, F.; Fouda-Onana, F.; Sicardy, O.; Guillet, N., Synthesis and Characterization of Electrocatalysts for the Oxygen Evolution in PEM Water Electrolysis. Int. J. Hydrogen Energy. 2011, 36, 10474-10481.

17. Reier, T.; Pawolek, Z.; Cherevko, S.; Bruns, M.; Jones, T.; Teschner, D.; Selve, S.; Bergmann, A.; Nong, H. N.; Schlögl, R.; Mayrhofer, K. J. J.; Strasser, P., Molecular Insight in Structure and Activity of Highly Efficient, Low-Ir Ir-Ni Oxide Catalysts for Electrochemical Water Splitting (OER). J. Am. Chem. Soc. 2015, 137, 13031-13040. 
18. Marshall, A.; Børresen, B.; Hagen, G.; Tsypkin, M.; Tunold, R., Electrochemical Characterisation of $\operatorname{Ir}_{\mathrm{x}} \mathrm{Sn}_{1-\mathrm{x}} \mathrm{O}_{2}$ Powders as Oxygen Evolution Electrocatalysts. Electrochim. Acta. 2006, 51, 3161-3167.

19. Di Blasi, A.; D'Urso, C.; Baglio, V.; Antonucci, V.; Arico, A. S.; Ornelas, R.; Matteucci, F.; Orozco, G.; Beltran, D.; Meas, Y.; Arriaga, L. G., Preparation and Evaluation of $\mathrm{RuO}_{2}-\mathrm{IrO} \mathrm{IO}_{2}, \mathrm{IrO}_{2}-\mathrm{Pt}$ and $\mathrm{IrO}_{2}-\mathrm{Ta}_{2} \mathrm{O}_{5}$ Catalysts for the Oxygen Evolution Reaction in an SPE Electrolyzer. J. Appl. Electrochem. 2009, 39, 191-196.

20. Marshall, A.; Børresen, B.; Hagen, G.; Sunde, S.; Tsypkin, M.; Tunold, R., Iridium Oxide-Based Nanocrystalline Particles as Oxygen Evolution Electrocatalysts. Russ. J. Electrochem. 2006, 42, 1134-1140.

21. Cheng, J.; Zhang, H.; Ma, H.; Zhong, H.; Zou, Y., Preparation of $\operatorname{Ir}_{0.4} \mathrm{Ru}_{0.6} \mathrm{Mo}_{x} \mathrm{O}_{\mathrm{y}}$ for Oxygen Evolution by Modified Adams' Fusion Method. Int. J. Hydrogen Energy. 2009, $34,6609-6613$.

22. Pérez-Viramontes, N. J.; Escalante-García, I. L.; Guzmán-Martínez, C.; GalvánValencia, M.; Durón-Torres, S. M., Electrochemical Study of Ir-Sn-Sb-O Materials as 
Catalyst-Supports for the Oxygen Evolution Reaction. J. Appl. Electrochem. 2015, 45,

$1165-1173$.

23. Reier, T.; Oezaslan, M.; Strasser, P., Electrocatalytic Oxygen Evolution Reaction (OER) on Ru, Ir, and Pt Catalysts: A Comparative Study of Nanoparticles and Bulk Materials. ACS Catal. 2012, 2, 1765-1772.

24. Oh, H. S.; Nong, H. N.; Reier, T.; Gliech, M.; Strasser, P., Oxide-Supported Ir Nanodendrites with High Activity and Durability for the Oxygen Evolution Reaction in Acid PEM Water Electrolyzers. Chem. Sci. 2015, 6, 3321-3328.

25. Kinoshita, K., Carbon: Electrochemical and Physicochemical Properties. John Wiley \& Sons: New York, 1988.

26. Cognard, G. Electrocatalyseurs À Base d'Oxydes Métalliques Poreux Pour Pile À Combustible à Membrane Échangeuse de Protons. Université Grenoble Alpes, France, 2017. 
27. Ávila-Vázquez, V.; Cruz, J. C.; Galván-Valencia, M.; Ledesma-García, J.; Arriaga,

L. G.; Guzmán, C.; Durón-Torres, S. M., Electrochemical Study of Sb-Doped $\mathrm{SnO}_{2}$ Supports on the Oxygen Evolution Reaction: Effect of Synthesis Annealing Time. Int. J. Electrochem. Sci. 2013, 8, 10586-10600.

28. Ma, L.; Sui, S.; Zhai, Y., Investigations on High Performance Proton Exchange Membrane Water Electrolyzer. Int. J. Hydrogen Energy. 2009, 34, 678-684.

29. Fuentes, R. E.; Farell, J.; Weidner, J. W., Multimetallic Electrocatalysts of Pt, Ru, and Ir Supported on Anatase and Rutile $\mathrm{TiO}_{2}$ for Oxygen Evolution in an Acid Environment. Electrochem. Solid-State Lett. 2011, 14, E5-E7.

30. Gottesfeld, S.; Srinivasan, S., Electrochemical and Optical Studies of Thick Oxide Layers on Iridium and Their Electrocatalytic Activities for the Oxygen Evolution Reaction. J. Electroanal. Chem. Interfacial Electrochem. 1978, 86, 89-104.

31. Reier, T.; Teschner, D.; Lunkenbein, T.; Bergmann, A.; Selve, S.; Kraehnert, R.; Schlögl, R.; Strasser, P., Electrocatalytic Oxygen Evolution on Iridium Oxide: Uncovering 
Catalyst-Substrate Interactions and Active Iridium Oxide Species. J. Electrochem. Soc.

2014, 161, F876-F882.

32. Danilovic, N.; Subbaraman, R.; Chang, K. C.; Chang, S. H.; Kang, Y.; Snyder, J.;

Paulikas, A. P.; Strmcnik, D.; Kim, Y. T.; Myers, D.; Stamenkovic, V. R.; Markovic, N. M.,

Using Surface Segregation to Design Stable Ru-Ir Oxides for the Oxygen Evolution

Reaction in Acidic Environments. Angew. Chem. Int. Ed. 2014, 53, 14016-14021.

33. Kötz, R.; Neff, H.; Stucki, S., Anodic Iridium Oxide Films: XPS-Studies of Oxidation

State Changes and $\mathrm{O}_{2}$-Evolution. J. Electrochem. Soc. 1984, 131, 72-77.

34. Kolotyrkin, Y. M.; Losev, V. V.; Chemodanov, A. N., Relationship between

Corrosion Processes and Oxygen Evolution on Anodes Made from Noble Metals and

Related Metal Oxide Anodes. Mater. Chem. Phys. 1988, 19, 1-95.

35. Elzanowska, H.; Birss, V. I., Reversible Ageing of Iridium Oxide Electrodes in Acidic Solutions. J. Appl. Electrochem. 1993, 23, 646-654. 
36. Saveleva, V. A.; Wang, L.; Teschner, D.; Jones, T.; Gago, A. S.; Friedrich, K. A.;

Zafeiratos, S.; Schlögl, R.; Savinova, E. R., Operando Evidence for a Universal Oxygen

Evolution Mechanism on Thermal and Electrochemical Iridium Oxides. J. Phys. Chem.

Lett. 2018, 9, 3154-3160.

37. Sanchez Casalongue, H. G.; Ng, M. L.; Kaya, S.; Friebel, D.; Ogasawara, H.;

Nilsson, A., In Situ Observation of Surface Species on Iridium Oxide Nanoparticles During the Oxygen Evolution Reaction. Angew. Chem. 2014, 53, 7169-72.

38. Cognard, G.; Ozouf, G.; Beauger, C.; Berthomé, G.; Riassetto, D.; Dubau, L.; Chattot, R.; Chatenet, M.; Maillard, F., Benefits and Limitations of Pt Nanoparticles Supported on Highly Porous Antimony-Doped Tin Dioxide Aerogel as Alternative Cathode Material for Proton-Exchange Membrane Fuel Cells. Appl. Catal. B. 2017, 201, 381-390.

39. Freakley, S. J.; Ruiz-Esquius, J.; Morgan, D. J., The X-Ray Photoelectron Spectra of Ir, $\mathrm{IrO}_{2}$ and $\mathrm{IrCl}_{3}$ Revisited. Surf. Interface Anal. 2017, 49, 794-799.

40. Cherevko, S.; Geiger, S.; Kasian, O.; Kulyk, N.; Grote, J.-P.; Savan, A.; Shrestha, B. R.; Merzlikin, S.; Breitbach, B.; Ludwig, A.; Mayrhofer, K. J. J., Oxygen and Hydrogen 
Evolution Reactions on $\mathrm{Ru}, \mathrm{RuO}_{2}$, Ir, and $\mathrm{IrO}_{2}$ Thin Film Electrodes in Acidic and Alkaline Electrolytes: A Comparative Study on Activity and Stability. Catal. Today. 2016, 262, 170180.

41. Lettenmeier, P.; Majchel, J.; Wang, L.; Saveleva, V. A.; Zafeiratos, S.; Savinova, E. R.; Gallet, J. J.; Bournel, F.; Gago, A. S.; Friedrich, K. A., Highly Active Nano-Sized Iridium Catalysts: Synthesis and Operando Spectroscopy in a Proton Exchange Membrane Electrolyzer. Chem. Sci. 2018, 9, 3570-3579.

42. Ardizzone, S.; Fregonara, G.; Trasatti, S., "Inner" and "Outer" Active Surface of $\mathrm{RuO}_{2}$ Electrodes. Electrochim. Acta. 1990, 35, 263-267.

43. Cherevko, S.; Geiger, S.; Kasian, O.; Mingers, A.; Mayrhofer, K. J. J., Oxygen Evolution Activity and Stability of Iridium in Acidic Media. Part 1. - Metallic Iridium. J. Electroanal. Chem. 2016, 773, 69-78.

44. Cherevko, S.; Geiger, S.; Kasian, O.; Mingers, A.; Mayrhofer, K. J. J., Oxygen Evolution Activity and Stability of Iridium in Acidic Media. Part 2. - Electrochemically Grown Hydrous Iridium Oxide. J. Electroanal. Chem. 2016, 774, 102-110. 
45. Pfeifer, V.; Jones, T. E.; Velasco Velez, J. J.; Arrigo, R.; Piccinin, S.; Havecker, M.;

Knop-Gericke, A.; Schlögl, R., In Situ Observation of Reactive Oxygen Species Forming on Oxygen-Evolving Iridium Surfaces. Chem. Sci. 2017, 8, 2143-2149.

46. Schlögl, K.; Mayrhofer, K. J. J.; Hanzlik, M.; Arenz, M., Identical-Location TEM Investigations of $\mathrm{Pt} / \mathrm{C}$ Electrocatalyst Degradation at Elevated Temperatures. $\mathrm{J}$. Electroanal. Chem. 2011, 662, 355-360.

47. Cherevko, S.; Zeradjanin, A. R.; Topalov, A. A.; Kulyk, N.; Katsounaros, I.; Mayrhofer, K. J. J., Dissolution of Noble Metals During Oxygen Evolution in Acidic Media. ChemCatChem. 2014, 6, 2219-2223.

48. Cherevko, S.; Reier, T.; Zeradjanin, A. R.; Pawolek, Z.; Strasser, P.; Mayrhofer, K. J. J., Stability of Nanostructured Iridium Oxide Electrocatalysts During Oxygen Evolution Reaction in Acidic Environment. Electrochem. Com. 2014, 48, 81-85.

49. Pourbaix, M., Atlas of Electrochemical Equilibria in Aqueous Solutions. Pergamon: 1966; Vol. 1. 
50. Castanheira, L.; Silva, W. O.; Lima, F. H. B.; Crisci, A.; Dubau, L.; Maillard, F., Carbon Corrosion in Proton-Exchange Membrane Fuel Cells: Effect of the Carbon Structure, the Degradation Protocol, and the Gas Atmosphere. ACS Catal. 2015, 5, 21842194.

51. Durst, J.; Lamibrac, A.; Charlot, F.; Dillet, J.; Castanheira, L. F.; Maranzana, G.; Dubau, L.; Maillard, F.; Chatenet, M.; Lottin, O., Degradation Heterogeneities Induced by Repetitive Start/Stop Events in Proton Exchange Membrane Fuel Cell: Inlet vs. Outlet and Channel vs. Land. Appl. Catal. B. 2013, 138-139, 416-426.

52. Cognard, G.; Ozouf, G.; Beauger, C.; Dubau, L.; López-Haro, M.; Chatenet, M.; Maillard, F., Insights into the Stability of Pt Nanoparticles Supported on Antimony-Doped Tin Oxide in Different Potential Ranges. Electrochim. Acta. 2017, 245, 993-1004.

53. Li, T.; Kasian, O.; Cherevko, S.; Zhang, S.; Geiger, S.; Scheu, C.; Felfer, P.; Raabe, D.; Gault, B.; Mayrhofer, K. J. J., Atomic-Scale Insights into Surface Species of Electrocatalysts in Three Dimensions. Nature Catal.. 2018, 1, 300-305. 
54. Minguzzi, A.; Lugaresi, O.; Achilli, E.; Locatelli, C.; Vertova, A.; Ghigna, P.;

Rondinini, S., Observing the Oxidation State Turnover in Heterogeneous Iridium-Based

Water Oxidation Catalysts. Chem. Sci. 2014, 5, 3591-3597.

55. Minguzzi, A.; Locatelli, C.; Lugaresi, O.; Achilli, E.; Cappelletti, G.; Scavini, M.;

Coduri, M.; Masala, P.; Sacchi, B.; Vertova, A.; Ghigna, P.; Rondinini, S., Easy

Accommodation of Different Oxidation States in Iridium Oxide Nanoparticles with Different

Hydration Degree as Water Oxidation Electrocatalysts. ACS Catal. 2015, 5, 5104-5115.

56. Pfeifer, V.; Jones, T. E.; Velasco Velez, J. J.; Massue, C.; Greiner, M. T.; Arrigo,

R.; Teschner, D.; Girgsdies, F.; Scherzer, M.; Allan, J.; Hashagen, M.; Weinberg, G.;

Piccinin, S.; Havecker, M.; Knop-Gericke, A.; Schlögl, R., The Electronic Structure of Iridium Oxide Electrodes Active in Water Splitting. Phys. Chem. Chem. Phys. 2016, 18, 2292-6.

57. Pfeifer, V.; Jones, T. E.; Wrabetz, S.; Massue, C.; Velasco Velez, J. J.; Arrigo, R.;

Scherzer, M.; Piccinin, S.; Havecker, M.; Knop-Gericke, A.; Schlogl, R., Reactive Oxygen Species in Iridium-Based OER Catalysts. Chem Sci. 2016, 7, 6791-6795. 
58. Rossmeisl, J.; Logadottir, A.; Nørskov, J. K., Electrolysis of Water on (Oxidized)

Metal Surfaces. Chem. Phys. 2005, 319, 178-184.

59. Rossmeisl, J.; Qu, Z. W.; Zhu, H.; Kroes, G. J.; Nørskov, J. K., Electrolysis of Water on Oxide Surfaces. J. Electroanal. Chem. 2007, 607, 83-89.

60. Fierro, S.; Nagel, T.; Baltruschat, H.; Comninellis, C., Investigation of the Oxygen Evolution Reaction on $\mathrm{Ti} / / \mathrm{IO}_{2}$ Electrodes Using Isotope Labelling and on-Line Mass Spectrometry. Electrochem. Com. 2007, 9, 1969-1974.

61. Geiger, S.; Kasian, O.; Ledendecker, M.; Pizzutilo, E.; Mingers, A. M.; Fu, W. T.; Diaz-Morales, O.; Li, Z.; Oellers, T.; Fruchter, L.; Ludwig, A.; Mayrhofer, K. J. J.; Koper, M. T. M.; Cherevko, S., The Stability Number as a Metric for Electrocatalyst Stability Benchmarking. Nature Catal. 2018, 1, 508-515.

62. Grimaud, A.; Demortière, A.; Saubanère, M.; Dachraoui, W.; Duchamp, M.; Doublet, M.-L.; Tarascon, J.-M., Activation of Surface Oxygen Sites on an Iridium-Based Model Catalyst for the Oxygen Evolution Reaction. Nature Energy. 2016, 2, 16189. 
63. Grimaud, A.; Diaz-Morales, O.; Han, B.; Hong, W. T.; Lee, Y. L.; Giordano, L.;

Stoerzinger, K. A.; Koper, M. T. M.; Shao-Horn, Y., Activating Lattice Oxygen Redox Reactions in Metal Oxides to Catalyse Oxygen Evolution. Nat. Chem. 2017, 9, 457-465.

64. Kasian, O.; Grote, J. P.; Geiger, S.; Cherevko, S.; Mayrhofer, K. J. J., The Common Intermediates of Oxygen Evolution and Dissolution Reactions During Water Electrolysis on Iridium. Angew. Chem., Int. Ed. Engl. 2018, 57, 2488-2491.

65. Abbott, D. F.; Lebedev, D.; Waltar, K.; Povia, M.; Nachtegaal, M.; Fabbri, E.; Copéret, C.; Schmidt, T. J., Iridium Oxide for the Oxygen Evolution Reaction: Correlation between Particle Size, Morphology, and the Surface Hydroxo Layer from Operando XAS. Chem. Mater. 2016, 28, 6591-6604. 


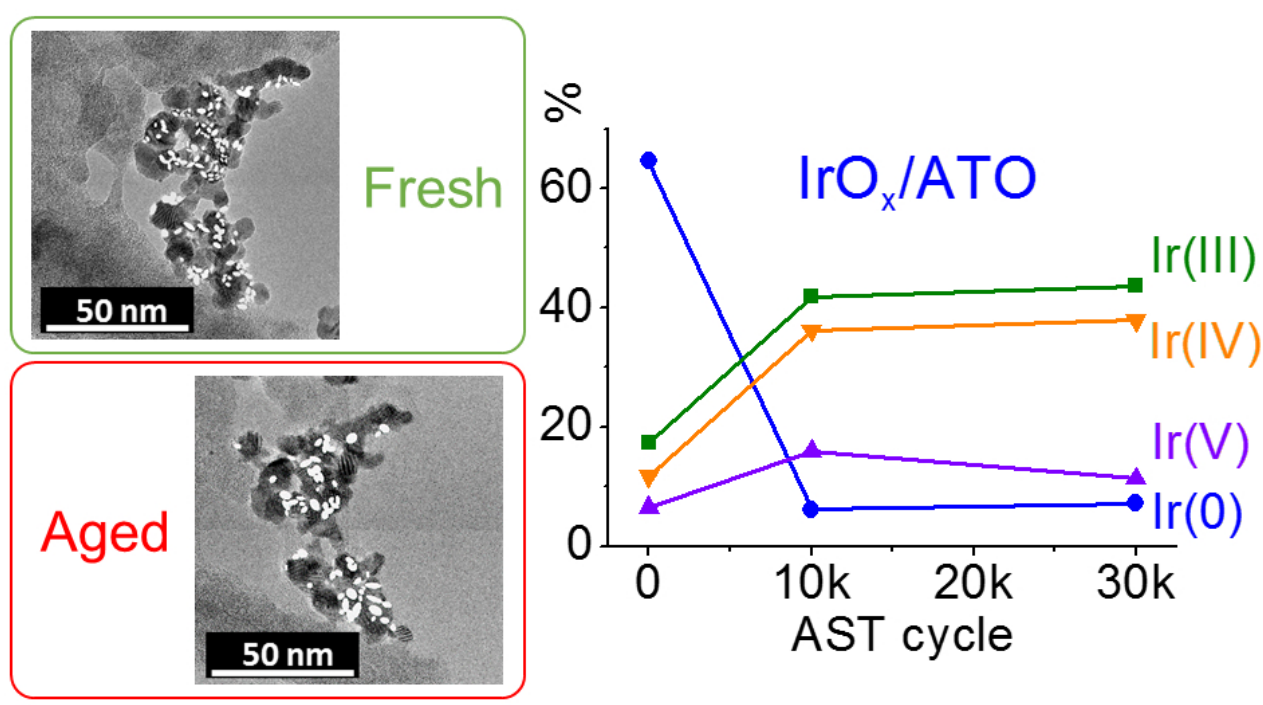

Identical-location transmission electron microscopy, X-ray photoelectron spectroscopy and electrochemistry were combined to unravel the degradation mechanisms of iridium oxide nanoparticles in oxygen evolution reaction conditions.

$82 \times 44 \mathrm{~mm}(300 \times 300$ DPI $)$ 